\title{
The temporal dimension of parental employment: Fixed-term contracts, non-standard work schedules and children's education in Germany
}

Bastian A. Betthäuser ${ }^{1,2,3,4}$, Nhat An Trinh ${ }^{4,5}$, Anette Eva Fasang ${ }^{6,7}$

ABSTRACT: The increasing prevalence of non-standard employment and its adverse consequences are well documented. However, we still know little about how prevalent non-standard employment is amongst parents, and whether its negative consequences are further transmitted to their children. Using data from the German Microcensus, we provide a detailed account of the prevalence of fixed-term employment and non-standard work schedules in households with children in Germany. Second, we examine the extent to which variation in this temporal dimension of parents' employment is associated with their children's educational attainment. We find that in about half of all German households with children in lower secondary education, at least one parent has a short fixed-term contract or regularly works on evenings or Saturdays. Depending on the concentration of parental non-standard employment in the household, children of parents with fixed-term contracts or non-standard work schedules have a 5 to 16 percent lower probability of being in the academic educational track than children with parents in standard employment, net of parents' social class, income and education. Based on these results, we argue that the temporal dimension of parental employment is key to understanding how changing labor markets reshape the opportunity structure for children from disadvantaged parental backgrounds and the intergenerational transmission of inequality.

Keywords: Inequality, Employment, Education, Insecurity, Intergenerational social mobility, Work schedules, Precarious work, Non-standard employment, Atypical employment, Fixed-term employment

Acknowledgements: The authors gratefully acknowledge the respondents of the German Microcensus for their participation and the statistical offices of the Länder and the Federal Statistical Office for collecting and managing this data. The authors would also like to thank the participants of the Sociology Writing Workshop at Humboldt University and the WZB Berlin Social Science Research Center for their valuable feedback.

Funding: This work was supported by the Oxford/Berlin Research Partnership [OXBER_SOC1] and the John Fell Fund [8380]. Research for this contribution is part of the Cluster of Excellence "Contestations of the Liberal Script" [EXC 2055, Project-ID 390715649], funded by the Deutsche Forschungsgemeinschaft (DFG, German Research Foundation) under Germany's Excellence Strategy.

\footnotetext{
${ }_{1}^{1}$ Observatoire Sociologique du Changement (OSC), Sciences Po

2 Nuffield College, University of Oxford

${ }^{3}$ Leverhulme Centre for Demographic Science, University of Oxford

${ }^{4}$ Department of Social Policy and Intervention, University of Oxford

${ }^{5}$ Wolfson College, University of Oxford

${ }^{6}$ Humboldt University Berlin

7 Wissenschaftszentrum Berlin für Sozialforschung (WZB)

* To whom correspondence may be addressed: bastian.betthaeuser@sciencespo.fr, Observatoire Sociologique du Changement (OSC), Sciences Po, 27 Rue Saint-Guillaume 75337 Paris, France
} 


\section{Introduction}

Employment conditions in modern labor markets are increasingly diverging from the standard of permanent employment and regular work schedules that characterized the 'golden age' of economic growth and prosperity in the decades following World War II. This concerns particularly the temporal dimension of employment, as a growing share of the labor force in economically advanced societies is employed on fixed-term contracts or has work schedules that do not conform to the 'nine-to-five-Monday-to-Friday' work week. Between 1985 and 2019, the proportion of dependent workers on fixed-term contracts grew by about 40 percent in the European Union (OECD, 2020). By 2019, one in seven dependent employees in the European Union, and one in eight dependent employees in Germany, was employed on a fixed-term contract (ibid.). At the same time, there has been a significant rise in casual and on-call jobs that are characterized by nonstandard work schedules (Kalleberg, 2011; Allmendinger, Hipp, and Stuth, 2013).

A growing body of evidence demonstrates significant adverse consequences of nonstandard employment. Individuals in fixed-term employment or with non-standard work schedules report lower levels of economic security (Kalleberg, Reskin, and Hudson, 2000; Kalleberg, 2009; McGovern, Smeaton, and Hill, 2004; Gash and Inanc, 2013), physical health (Virtanen et al., 2005; Harrington, 2001; Benach et al., 2014; Zhao et al., 2019) and psychological wellbeing (Costa and Sartori, 2005; Schneider and Harknett, 2019), compared to individuals in permanent employment and with standard work schedules.

While numerous studies document the rise of non-standard employment and its consequences for people in such forms of employment, there is little evidence (1) on how common non-standard employment is in households with children and (2) on the extent to which the adverse consequences of non-standard employment for parents are further transmitted to their children.

The literature on developmental psychology suggests that, among others, parental economic insecurity, parental stress, parental ill-health and reductions in parent-child time can negatively impact children's development and educational attainment (Brooks-Gunn et al., 1995; Barlow and Axford, 2014). These characteristics are likely to be concentrated amongst people in non-standard employment, with negative consequences for children of parents in such positions. If this was the case, the expansion of fixed-term employment and non-standard work schedules could entrench the intergenerational transmission of disadvantage and obstruct the social mobility chances of children born into households with parents in non-standard employment.

Despite the substantial increase of non-standard employment in the last decades and the potentially large implications for the intergenerational transmission of disadvantage, the existing literature on social mobility has thus far largely neglected the issue of parental non-standard employment. Instead, most studies continue to focus on the classic social background categories of parental class, parental status, parental income and parental education (Bukodi and Goldthorpe, 2018; Major and Machin, 2018). We argue that examining the role of parental non-standard employment in shaping children's life chances is critical, both because of the growing prominence of non-standard employment and because the distributions of fixed-term contracts and nonstandard work schedules are likely to cut across the classic categories of social background noted above. In light of the increasing prevalence of fixed-term employment and non-standard work schedules, research in social stratification and mobility should devote more attention particularly to the temporal dimension of parental employment. This becomes all the more important, as the 
share of mothers in the labor market is growing and as dual-earner households with children are becoming more common (Bianchi, 2000).

We conceptualize the temporal dimension of parental employment as comprised of two elements. The first element refers to the length of the employment contract that parents hold. As discussed in further detail below, whether parents' employment contract is permanent or fixedterm, as well as the length of the fixed-term contract, can be expected to affect parents' real and perceived economic insecurity, their physical and mental wellbeing, their capacity for childcentered parenting, the aspirations they have for their children's educational trajectory and the educational choices they make for and with their children.

The second component of the temporal dimension of parental employment concerns parents' daily work schedules. As we elaborate below, parents' work schedules may have significant consequences for their children's development and education if they lead to a reduction in the time parents spend with their children. Furthermore, physically or emotionally taxing work schedules that involve frequent evening or weekend work are likely to affect parents' physical and mental wellbeing and their capacity for supportive, child-centered parenting. However, if parents' have control over their work schedules, non-standard work schedules may also serve to increase the time that parent spend with their children and thereby have a positive bearing on children's development and education.

Evidence on the relationship between parental non-standard employment and children's life chances remains relatively scarce. Existing studies tend to focus on industry-specific samples, such as shift work in the nursing or the retail sector (e.g., Davis et al., 2006; Chait Barnett et al., 2008; Harknett et al., 2020), or only consider mothers' employment (e.g., Han, 2005; 2008; Miller and Han, 2008; Dunifon et al., 2013; Hsin and Felfe, 2014). We therefore lack population-level evidence on the prevalence of non-standard employment in households with children. Moreover, studies that consider characteristics of children from people in non-standard employment tend to focus on psychological and physical measures of child wellbeing and ability. These studies suggest that children of parents who work outside of the 'nine-to-five-Monday-to-Friday' work week are more likely to exhibit behavioral problems (Han, 2008; Han, Miller, and Waldfogel, 2010; Dunifon et al., 2013; Kaiser, Li, and Pollmann-Schult, 2019), higher levels of depression (Strazdins et al., 2006; Han and Miller, 2009), lower cognitive ability (Han, 2005; Han and Fox, 2011), and are at higher risk of overweight (Miller and Han, 2008; Champion et al., 2012; Li et al., 2019). ${ }^{1}$ However, we lack evidence on how mothers' and fathers' fixed-term employment and non-standard work schedules are associated with children's educational attainment. This is of concern, since children's educational attainment is known to be a key factor shaping their future labor market chances and their quality of life more broadly (Breen and Müller, 2020; Müller Steinmann and Ell, 1998).

The main theoretical contribution of our study is to conceptualize the temporal dimension of parental employment and to theorize its role in the intergenerational transmission of disadvantage. To this end, we bring together theoretical and empirical insights from the literature on non-standard employment, the literature on developmental psychology and the literature on intergenerational social mobility. Our paper makes four main empirical contributions. First, we leverage the large, nationally representative sample of the German Microcensus and its detailed information on parents' employment conditions to obtain population-level estimates of the prevalence and concentration of fixed-term employment and non-standard work schedules among households with children in Germany. Second, we shed light on the association between parents' fixed-term employment and children's educational attainment. Third, we examine the association 
between parents' frequency of working during evenings and on Saturdays and children's educational attainment. Fourth, we examine the extent to which different constellations of mothers' and fathers' fixed-term employment and non-standard work schedules within the household are associated with children's educational attainment.

We focus on Germany, as it constitutes an instructive case for examining the relationship between parental non-standard employment and children's education. Since the early 1990s, the German labor market underwent multiple structural changes, marked by a progressive flexibilization of labor market regulation, a retrenchment of the social protection system, a significant increase in non-standard employment, and a rise in women's labor market participation (Allmendinger, Hipp, and Stuth, 2013; Allmendinger et al., 2018). These structural changes are reflected in an increasingly 'dualized' labor market, with marked differences in the employment conditions and social protection of 'labor market insiders' in standard employment and 'labor market outsiders' in non-standard employment (Emmenegger et al., 2012; Brady and Biegert, 2017; Betthäuser, 2017). At the same time, the relationship between children's social background and their educational attainment remains particularly strong in Germany (Müller and Pollak 2010; Breen and Müller, 2020). In part, this has been attributed to the highly stratified education system, which separates children into three ability tracks during their secondary education. Children's school track at the lower-secondary level is known to shape their future educational trajectory, labor market career and life course (Müller, Steinmann and Ell, 199). Accordingly, and as discussed in further detail below, children's school track at the lower-secondary level constitutes the main outcome measure of our empirical analysis. In sum, considering the dual structure of the German labor market and the strong link between children's social background and their educational attainment, the country can be seen as a 'most-likely case', in which the relationship between parental non-standard employment and children's education can be expected to be relatively strong (c.f., Gerring, 2016).

\section{Parental fixed-term contracts, non-standard work schedules and children's education}

The psychological and sociological literature on child development highlights the importance of different types of parental resources for children's development and educational success. The resource framework developed by Brooks-Gunn and colleagues differentiates between four types of parental resources: financial resources, psychological resources, time and human capital (Brooks-Gunn et al., 1995).

Parental fixed-term employment is likely to mainly influence children's education through parents' financial and psychological resources. Fixed-term employment is strongly related to real and perceived economic insecurity. People in fixed-term employment are more likely to experience unemployment and an associated loss in income, which is exacerbated by their substantially reduced access to unemployment insurance and social benefits compared to individuals on permanent employment contracts (Kalleberg, 2009; 2011; Standing 2011, Betthäuser, 2017). The associated economic insecurity may limit parents' ability and willingness to commit economic resources to children's education and training. This is likely to concern particularly longer-term educational pathways, such as the academic school track in Germany, which requires more financial support from parents than the shorter educational pathway of completing vocational training, which also allows children to contribute income to the household. The economic insecurity associated with fixed-term employment may also limit parents' ability and readiness to 
commit resources to educational expenses, such as purchasing computer equipment and books or paying for out-of-school tutoring and summer school programs (Duncan and Brooks-Gunn, 1997; Kaushal, Magnuson, and Waldfogel, 2011; Reardon, 2011; Hao and Yeung, 2015).

In part due to the economic insecurity associated with fixed-term employment, individuals in fixed-term employment are more likely to report physical ill-health and reduced psychological well-being compared to permanent employees (Benach et al., 2014; Green, 2015; Artazcoz et al., 2005; Inanc, 2020). In turn, the reduced health and wellbeing of parents in fixed-term employment could affect their ability to support their children's emotional and cognitive development through child-centered parenting (e.g. De Graaf, De Graaf, and Kraaykamp, 2000; Farkas, 2003). Moreover, lower health and well-being may make it more difficult for parents on fixed-term contracts to help with homework, to attend parent-teacher meetings, and to monitor their child's progress in school (Murray et al., 2006; Bratti and Mendola, 2014). Considering that conflicts between parents and marital misfunctioning are more prevalent in families with fixed-term work (Kalleberg, 2018; Nolan et al., 2000), the negative implications for parents' mental health and wellbeing may further manifest in an unstable home learning environment.

In light of the implications of fixed-term employment on parents' economic and psychological resources, we expect parental fixed-term employment to be negatively associated with children's educational attainment. This association is likely to be especially strong for short parental fixed-term employment of less than one year, which is likely to have particularly severe consequences for parents' economic security as well as their mental health and wellbeing. As discussed in further detail below, we therefore differentiate between long and short fixed-term contracts in all our analyses.

Non-standard work schedules can be expected to affect children's education primarily through their impact on the amount of time parents can spend with their children when they are out of school. Working evening shifts may prevent parents to be present for young children's bedtime routines, to read bedtime stories to them, and to check-in with them at the end of the day, all of which has been shown to benefit children's emotional and cognitive development (e.g., Mindell and Williamson, 2018; Barone et al., 2019). Similarly, parents who work weekends may be unavailable for joint extracurricular activities, such as playing sports or going to the museum or theatre, which are known to foster children's development and educational success (Lareau, 2003; Hsin and Felfe, 2014). Importantly, evening and weekend work is likely to affect the time parents have to support their children with their homework and learning, providing them with guidance on educational decisions and attending parent-teacher meetings (Gracia and García-Román, 2018; Wight, Raley, and Bianchi, 2008).

Aside from its effect on the time parents can spend with their children, working on evenings and weekends may also cause physical and psychological strain. Individuals who frequently work evenings more often report chronic health conditions, sleep deprivation, neurotic disorders and depressive symptoms (Kantermann et al., 2010; Totterdell, 2005; Vogel et al., 2012; Perry-Jenkins et al., 2007). As noted above, lower parental health and wellbeing can interfere with parents' ability to focus on the needs and development of their children. Indeed, working evenings has been found to be associated with harsh and strict parenting practices, which in turn are linked to increased behavioral problems among children (Kaiser, Li, and Pollmann-Schult, 2019). Studies also report negative consequences of non-standard work schedules for family cohesion and stability (Schneider and Harknett, 2019; Presser, 2005; Chait Barnett, Gareis, and Brennan, 2008; 
Liu et al., 2011; Davis et al., 2008; Kalil, Ziol-Guest, and Levin Epstein, 2010), which might further affect the wellbeing, development and learning of children.

The dynamics discussed above suggest that parents' evening and weekend work is negatively associated with children's educational attainment. However, non-standard work schedules could also allow dual-earner couples to arrange their work in ways that allow them to spend more time with their children (Täht and Mills, 2012), which may benefit children's development and educational attainment.

Even more so than in other European countries, mothers in Germany still spend substantially more time than fathers caring for children and supporting them with homework and extracurricular activities (BFSFJ, 2015; Schober and Zoch, 2019; Zoch, Bächmann, and Vicari, 2020). Consequently, one may expect that the association between parents' non-standard employment and children's educational chances are more pronounced for mothers than for fathers. For instance, mothers' psychological and physical strain associated with fixed-term contracts and difficulties harmonizing non-standard work schedules with children's school schedules are particularly likely to affect children's educational development, given that mothers continue to be the primary care givers in Germany. Nevertheless, the specific constellations and concentration of mothers' and fathers' fixed-term contracts and non-standard work schedules in the household likely matter for children's development and educational success. If one of two parents is employed permanently and has a standard work schedule, this may mitigate the potentially adverse effects of the other partner's fixed-term employment or non-standard work schedule on children's educational attainment. Conversely, children growing up in households with two parents in non-standard employment are likely to be at a greater disadvantage than children for whom only one parent is in non-standard employment. The remainder of this article will examine whether the theoretical expectations discussed in this section are in line with the empirical evidence.

\section{Data and variables}

We use data from the German Microcensus collected between 2008 and 2015². The Microcensus is Germany's largest representative household survey and covers one percent of the population. Around 810,000 individuals in 370,000 households are interviewed each year and participation is mandatory. The Microcensus is a cross-sectional survey to secure highly representative population level data each year. As discussed in further detail below, it also contains a smaller panel element for a subset of respondents, which we use to replicate our analyses. It contains detailed information on the type and length of individuals' employment contracts and on their work schedules. Moreover, the large sample size also allows us to differentiate between different combinations of mothers' and fathers' fixed-term contracts and non-standard work schedules, including relatively rare combinations that may have the strongest negative effects on children's educational attainment. The Microcensus is the only data source in Germany that provides sufficient case numbers and has detailed enough information on parents' employment conditions in order to map constellations of both parents' non-standard work within households and to allow for a meaningful analysis of the association with children's educational attainment. Since the Microcensus does not follow children after they have moved out of the parental household, our sample consists of children below the age of sixteen who are in secondary education $(\mathrm{N}=64,160){ }^{3}$ 
The focal outcome variable of our study is children's school track at the lower-secondary level. At this level, children in Germany are in one of three ability tracks, which correspond to different school types. The highest ability track (the Gymnasium) allows children to complete the qualification necessary to enroll in university, while children who complete the two lower ability tracks (the Hauptschule and the Realschule) generally go on to enroll in vocational training programs. As noted above, whether children complete the academic track or one of the lower ability tracks thus has substantial implications for their future educational trajectories, labor market careers and life courses (Müller, Steinmann and Ell, 1998). Accordingly, we measure children's school track with a binary variable indicating whether a child is in the academic secondary track (the Gymnasium) or in one of the two lower ability tracks (Hauptschule or Realschule). ${ }^{4}$ In our sample, $50.86 \%$ of children who are in lower-secondary education are in the academic secondary track, while $49.14 \%$ are in one of the two vocational secondary tracks.

To examine the concentration of fixed-term employment contracts in the household, we generate a categorical variable for mothers' and fathers' employment status, respectively. This variable differentiates between mothers and fathers who are (1) employers or self-employed, (2) employed on a permanent contract, (3) employed on a fixed-term contract that is longer than one year, (4) employed on a fixed-term contract that spans one year or less, (5) unemployed, or (6) inactive.

With regards to parent's work schedules, we differentiate between individuals who (1) never, (2) sometimes, (3) regularly or (4) always work in the evening (between 6pm and 11pm) or on Saturdays, respectively. ${ }^{5}$ The distribution of mothers' and fathers' employment statuses and work schedules is shown in the next section.

As discussed further below, we control for net household income and for mothers' and fathers' education and social class position. In the Microcensus, net household income is measured in twenty brackets, as shown in Figure 1. Given that there is a linear association between this measure of net household income and children's educational track placement, we treat this measure as a continuous variable and standardize it by survey wave. Parents social class is measured using the European Socio-economic Classification (ESeC) (see Rose and Harrison, 2010). Table 1 shows the categories and the distribution of our measures of mothers' and fathers' school-leaving qualification, highest professional qualification, and social class, respectively.

Given the cross-sectional structure of the Microcensus, we observe parents' attributes at the same time as children's secondary school track. Considering that children in Germany can change school tracks during their secondary education and that about a quarter of students makes use of this possibility (Buchholz and Schier, 2015), it is not clear whether measuring parents' attributes at the same time as children's secondary school track or measuring parents' attributes prior to children's transition to secondary education would be preferable. We therefore replicate our results using a subsample of the Microcensus $(N=5,748)$ which can be followed over multiple waves of data collection and for which we observe parental attributes in the year before children transitioned to secondary education. As discussed in further detail below, our findings hold when we replicate our analyses using this smaller panel sample. Furthermore, using this subsample, we find no systematic patterns in which parents' contract type or work schedule changes when their children transition from primary to secondary education. In fact, we find that parents' contract type and work schedule before their children's transition to secondary education are highly predictive of parents' contract type and work schedule after this transition. The composition of the panel subsample also closely resembles the composition of our main analytical sample with 
respect to parents' income, school-leaving qualification, highest professional qualification, and social class (see Table A1 and Figure A1 in the Online Supplement).

- Figure 1 -

- Table 1 -

\section{Results I: Prevalence of fixed-term contracts, evening work and Saturday work}

The first empirical aim of our study is to leverage the large, nationally representative sample of the German Microcensus and its detailed information on parents' employment conditions to obtain population-level estimates of the prevalence and concentration of fixed-term employment and non-standard work schedules among households with children below the age of sixteen who are in secondary education in Germany. Table 2 cross-tabulates mothers' and fathers' employment status. ${ }^{6}$ All percentages refer to the share of children with mothers and fathers in the respective employment category. Having a permanent contract remains the most common, 'standard' employment status for fathers and has also become the most common status for mothers. About 65 percent of children have a father on a permanent contract and about 61 percent of children have a mother on a permanent contract. About 41 percent of children live in dual earner households in which both the mother and the father are employed on a permanent contract.

The share of children with mothers and fathers employed on fixed-term employment contracts is highlighted by the gray shade in Table 2. Fixed-term contracts are more common for mothers than for fathers, and there is a sizeable share of children whose mother is employed on a fixed-term contract ( 5 percent) or whose father is employed on a fixed-term contract (3 percent). More detailed analyses show that for both mothers and fathers, short fixed-term contracts of less than one year are more common than longer fixed-term contracts (see Table A2 in the Online Supplement). Examples of the most common occupations with short fixed-term contracts are scouts, sales personnel, and care workers for mothers, and lorry drivers, assembly line workers and construction workers for fathers. Some of the most common occupations with long fixed-term contracts are social workers, office clerks and social scientists for mothers and directors and chief executives, medics, architects and engineers for fathers.

Most children whose mother has a fixed-term contract either live with a father on a permanent contract, or without a father in the household (Table 2). This suggests a polarization of households, in which potentially negative consequences of maternal fixed-term employment are either compensated by a main breadwinner or are aggravated by the lack of a second earner.

- Table 2 -

Table 3 shows the share of children according to mothers' and fathers' frequency of working during evenings, differentiating parents who (1) never, (2) sometimes, or (3) regularly/always work during evenings. ${ }^{7}$ As highlighted by the gray shade in Table 3, about 15 percent of children have mothers who regularly or always work during evenings and about 25 percent of children have fathers who regularly or always work during evenings. About 5 percent of children live in households in which both parents regularly or always work during evenings.

- Table 3 - 
Table 4 shows the share of children according to mothers' and fathers' frequency of working on Saturdays, differentiating parents who (1) never, (2) sometimes, or (3) regularly/always (highlighted in gray) work on Saturdays. ${ }^{8}$ As highlighted by the gray shade in Table 4, about 18 percent of children have mothers who regularly or always work on Saturdays and about 20 percent of children have fathers who regularly or always work on Saturdays. About 5 percent of children live in households in which both parents regularly or always work on Saturdays.

The most common occupations of people with non-standard work schedules are similar for evening and Saturday work. Examples of occupations in which people regularly or always work during evenings or on Saturdays are nurses, shop sales assistants, scouts and waiters for mothers, and managing directors and chief executives, machine operators, shop sales assistants, and truck and lorry drivers for fathers.

\section{- Table 4 -}

Table 3 and Table 4 show that most children whose mother regularly or always works during evenings or Saturday either live with a father who also regularly or always works during evenings or Saturday, without a father in the household, or with a father who never works during evenings or Saturdays. As for parents' employment status, this suggests a polarization of households with regards to parents' work schedules, in which potentially negative consequences of maternal nonstandard work schedules may be compensated by a father with a standard working schedule or may be aggravated by the lack of a second earner or by the father having a non-standard work schedule as well.

Figure 2 shows the extent to which fixed-term employment and non-standard work schedules are concentrated in households. More specifically, it shows all possible constellations of short-fixed term employment and non-standard work schedules amongst different household types. This figure is based on two binary measures. The first binary measure indicates whether or not mothers and fathers have a fixed-term contract of less than one year. 'The second binary measure, indicates whether or not mothers and fathers work regularly or always in the evening or on Saturdays. Households in which the mother and/or the father does not live in the household or is not employed are labelled accordingly. Household types are ordered according to the proportion of children living in the respective household types, as illustrated by the black bars.

\section{- Figure 2 -}

The top row of Figure 2 shows that about 26 percent of children live in households in which both parents are permanently employed and have standard work-schedules. The gray shades in Figure 2 indicate household types in which at least one parent has a short fixed-term contract or a nonstandard work schedule. Importantly, adding up these categories, we find that about 48 percent of children live in such households. In other words, almost half of all children have at least one parent with a non-standard contract or work-schedule.

The most prevalent household type with parents in non-standard employment consists of households in which the father works a non-standard schedule and has a contract that is longer than a year and in which the mother has a standard work schedule and a contract that is longer than a year (about 14 percent of children live in such household). Other prevalent household types consist of households in which both parents work non-standard schedules and are in long-term employment (about 8 percent of children), households in which the mother works a non-standard schedule and has a long-term contract, while the father has both a standard work schedule and a 
long-term contract (about 8 percent of children), households in which the mother is not employed and the father works a non-standard work schedule and has a long-term contract (about 7 percent of children), and households in which the father does not live in the household and the mother has a non-standard work schedule and a long-term contract (about 4 percent of children). With the important exception of households in which both parents work non-standard schedules, concentration of non-standard work schedules and short fixed-term employment is relatively uncommon. If we add up the proportion of children living in household types in which one or both parents have both a non-standard schedule and a short fixed-term contract, we find that about 2 percent of children live in such households - a small but non-negligible share.

\section{Results II: Fixed-term employment contracts and children's education}

Our second aim is to examine the association between mothers' and fathers' fixed-term employment contracts and children's educational attainment. To this end, we estimate linear probability models and regress our binary outcome variable of children's educational track on our categorical measure of mothers' and fathers' employment status, using the most common status of 'having a permanent contract' as the reference category. ${ }^{10}$ Mother's and father's employment statuses are included in the same model, so that we always control for the other parent's employment status. We also control for net household income, parental class and parental education in all our models. Accordingly, any association we find between parents' employment status and children's school track is net of parents' income, class and education.

$$
\text { - Figure } 3 \text { - }
$$

Figure 3 shows the coefficients for our measure of parental employment status (see Table A5 for the full model). Net of parental income, class and education, children of mothers employed on short fixed-term contracts are, on average, about 3 percent less likely to be in the highest educational track, as compared to children with mothers in permanent employment. This constitutes a sizable disadvantage, considering, for instance, that maternal unemployment is associated with a 5 percent lower likelihood of being in the academic track. By contrast, we find no evidence that having a mother with a fixed-term contract that is longer than one year, or having a father with a fixed-term contract (either long or short), is associated with a lower likelihood of being in the academic track, net of parental income, class and education. As noted above, we replicate our results using a subsample of the Microcensus which can be followed over multiple waves of data collection and for which we observe parental attributes in the year before children's transition to secondary education. While the smaller sample size $(\mathrm{N}=5748)$ leads to less precise estimates, the analysis of this sample confirms the empirical pattern that particularly mother's short fixed-term employment is associated with children having a lower likelihood of being in the highest educational track (see Figure A2 in the Online Supplement).

The observed difference in the association between mother's and father's having a short fixed-term contract and children's educational track may be due to the fact that mothers continue to be primary care-takers of children and spend more time with their children than fathers in the traditionally strong male breadwinner context of Germany (Trappe et al., 2015). ${ }^{11}$ Accordingly, children may be more affected by maternal stress and uncertainty related to fixed-term employment, relative to their father's employment status. Note that the most common occupations of mothers with short fixed-term contracts noted above are known for being 
economically precarious and mentally and/or physically straining. The data we use do not permit us to verify whether the negative association between mother's short fixed-term employment and children's educational track is causal and whether it is mediated by mothers' economic uncertainty, physical strain or associated constraints on child-centered parenting. However, such mechanism would appear to be plausible and in line with the existing evidence on the negative effects of fixedterm employment on individuals' health and psychological wellbeing (see, e.g., Inanc, 2020).

\section{Results III: Evening work, Saturday work and children's education}

Our third aim is to examine the association between children's education and parents working during evenings and on Saturdays. To this end, we regress our binary outcome variable of children's educational track on our measure of mothers' and fathers' frequency of working during evenings or on Saturdays, using the category of never working on evenings/Saturdays as the reference category and controlling for parents' employment status, income, class and education. Figure 4 and Figure 5 show the coefficients for our measures of parents' frequency of working in the evenings and on Saturdays, respectively (see Table A6 for the full model).

- Figure 4 -

- Figure 5 -

Figure 4 shows a significant negative association between mothers working on evenings and children's educational track. After controlling for parents' employment status, net household income and education, children whose mother always works during the evening are about 4 percentage points less likely to be in the academic track than children whose mother never works in the evening. We see a clear empirical pattern whereby the likelihood of children being in the high educational track declines as the frequency of mothers working on evenings increases.

Interestingly, we find no association between fathers working evenings and children's educational track. This result parallels our finding that there appears to be no association between father's fixed-term employment and children's educational track. As discussed above, this may be due to the continuing primary caretaker role of mothers in Germany, who tend to be more involved in children's upbringing and educational development than is the case for fathers.

Similar to the associations we find for mothers working during evenings, Figure 5 shows a strong negative association between mothers' working on Saturdays and children's educational track. Even after controlling for parents' employment status, net household income and education, children whose mother always works on Saturdays are about 5 percentage points less likely to be in the academic track than children whose mother never works on Saturdays. Again, we see a clear empirical pattern whereby the likelihood of children being in the academic secondary track declines with the frequency of mothers working on Saturdays.

Children whose father always works on Saturdays have around a 3 percentage points smaller chance to be in the academic educational track than children whose father does not work on Saturdays. However, unlike for mothers, we do not find any association between the likelihood of children being in the academic track and fathers working sometimes or regularly on Saturdays, net of parents' income, class and education. This corroborates the empirical pattern we find, whereby the link between father's non-standard employment and children's educational track seems to be weaker than the association between mother's non-standard employment and children's educational track. We find that this empirical pattern holds (albeit less precisely 
estimated) when we replicate our results with the subsample of the Microcensus for which we observe parental attributes before children transition to secondary education (see Figure A3 and Figure A4 in the Online Supplement).

\section{Results IV: Household types and children's education}

The fourth aim of the paper is to examine the extent to which different constellations of mothers' and fathers' fixed-term employment and non-standard work schedules within the household are associated with children's education. To this end, we regress our binary measure of children's educational track on our measure of the different household types that we discussed and presented above (see Figure 2), controlling for parents' income, class and education. Figure 6 shows the coefficients indicating the association between children's educational track and these different household types (see Table A7 for the full set of coefficients). Household types are ordered according to the proportion of children living in the respective household types. The most common household type - households in which both parents have a standard contract and work schedule - serves as the reference category (see Household Type 1 in Figure 6).

$$
\text { - Figure 6- }
$$

Figure 6 confirms the empirical pattern we found in the analyses presented above. The association between children's educational track and parental non-standard employment is stronger when the mother rather than the father is in non-standard employment. Children living in households in which the mother has a non-standard work schedule and a long-term contract, and in which the father has a standard work schedule and a long-term contract (Household Type 5), are about three percentage points less likely to be in the high educational track than children living in households in which both parents have a standard contract and a standard work schedule. By contrast, we find no negative association between children's educational track and the household type in which the father works a non-standard schedule and has a long-term contract and in which the mother has a standard work schedule and a long-term contract (Household Type 2). Children living in households in which parents have non-standard contracts have a lower likelihood (about 4 percent) of being in the high educational track if the mother has a short fixed-term contract (Household Type 14), but not if the father has a short-term contract (Household Type 21).

While households in which the mother or the father have both a non-standard work schedule and a non-standard contract are relatively uncommon, we find that children in households in which the mother has both a non-standard work schedule and a non-standard contract are particularly prone to attend one of the lower two educational tracks. Children in such households are about 8 percent less likely to attend the high educational track (relative to children for whom both parents have standard work schedules and standard contracts), even when their father has a standard work schedules and standard contracts (Household Type 18). Children whose mother has both a non-standard schedule and a non-standard contract and whose fathers are not employed (Household Type 29) are even less likely (about 15 percent) to attend the high educational track. Similarly, children living in households in which both the mother and the father have a non-standard work schedule and a non-standard contract (Household Type 31) are about 16 percent less likely to attend the high educational track. This suggests that, while still relatively uncommon, concentration of non-standard work schedules and non-standard contracts within 
households are associated with a particularly low propensity of children attending the high educational track.

\section{Conclusion}

The increasing prevalence of non-standard employment and its adverse consequences on workers in such positions are well documented. However, to date we still know little about how common non-standard employment is amongst parents, and whether its negative consequences are further transmitted to their children. This article has sought to address this gap, focusing on the temporal dimension of parental employment. We conceptualize the temporal dimension of parental employment as comprised of two elements; the first element refers to the length of the employment contract that parents hold and the second component concerns parents' daily work schedules.

To date, the temporal dimension of parental employment has been largely overlooked in the literature on the intergenerational transmission of inequality, which has focused on the more traditional measures of parental background, particularly parents' class, income, and education. We argue that expanding analyses of intergenerational transmission of disadvantage to consider the temporal dimension of parental employment will become increasingly important, given the rise of non-standard employment, both in European societies and the United States (Allmendinger, Hipp, and Stuth, 2013; OECD, 2010; Kalleberg, 2011). Moreover, the temporal dimension of parental employment is likely to play a key role in the intergenerational transmission of inequality in low- and middle-income countries, where informal work accounts for a large share of national labor markets (ILO, 2018).

The first empirical aim of our study was to leverage the large, nationally representative sample of the German Microcensus and its detailed information on parents' employment conditions to obtain population-level estimates of the prevalence and concentration of fixed-term employment and non-standard work schedules among households with children in Germany. We find that in about half of all German households with children in lower secondary education, at least one parent has a short fixed-term contract or regularly works on evenings or Saturdays. However, in most of these households only one of the two parents has a fixed-term contract or a non-standard contract, while the other parent has a standard employment contract and a standard work schedule. One important exception are households in which both the mother and the father regularly or always work evenings or Saturdays (about 8 percent of children in lower-secondary education live in such a household).

The second aim of our study was to shed light on the association between parents' fixedterm employment and children's educational attainment. We find that, net of parental income, class and education, particularly mothers' short fixed-term employment of less than one year is associated with a lower likelihood (about 3 percent) of their children to attend the academic school track. By contrast, we find no evidence of an association between fathers' fixed-term employment and children's school track.

Our third aim was to examine the association between parents' frequency of working during evenings and on Saturdays and children's educational attainment. Paralleling the results for parental fixed-term employment, we find that, net of parental income, class and education, particularly mothers' evening and Saturday work is associated with a lower likelihood (about 4 and 
5 percent, respectively) of their children to attend the academic school track. We find little evidence of an association between fathers' non-standard employment and children's school track.

The fourth aim of the paper was to examine the extent to which different constellations of mothers' and fathers' fixed-term employment and non-standard work schedules within the household are associated with children's educational attainment. Importantly, while household types in which the mother or the father have both a non-standard work schedule and a nonstandard contract are relatively uncommon, we find that children in households in which the mother has both a non-standard work schedule and a non-standard contract are substantially less likely (8 percent) to attend the academic school track. Similarly, children living in households in which both the mother and the father have both a non-standard work schedule and a non-standard contract are about 16 percent less likely to attend the high educational track. This suggests that, while still relatively uncommon, the concentration of non-standard work schedules and nonstandard contracts within households is associated with a particularly high educational disadvantage for children.

In sum, our study provides a descriptive account of the high prevalence of fixed-term contracts and non-standard work schedules amongst households with children in Germany. Furthermore, we show that particularly mothers' fixed-term employment and non-standard work schedules are negatively associated with children's educational chances. This association holds, even when mothers' and fathers' social class, income and education are taken into account. We argue that considering the temporal dimension of parental employment is therefore critical for understanding how changing labor markets reshape the opportunity structure for children from disadvantaged parental backgrounds and the intergenerational transmission of inequality. Given the recent rise of non-standard employment, research on the intergenerational transmission of inequality stands to benefit from considering the temporal dimension of parental employment as an important component of children's parental background.

The Microcensus is the only data source in Germany that provides sufficient case numbers and has detailed enough information on parents' employment conditions in order to map constellations of both parents' non-standard work within households and to allow for a meaningful analysis of the association with children's educational attainment. However, the German Microcensus does not permit us to examine whether this association is causal or due to unobserved characteristics of parents in non-standard employment. Similarly, it does not allow us to test our theoretical expectations with respect to the specific factors that may mediate the association between parents' non-standard employment and children's educational attainment. Moreover, the cross-sectional design of the Microcensus means that we observe parents' contract type and work schedule at the same time as we observe children's secondary school track. However, as discussed above, we replicated our results with the smaller panel subset of the Microcensus sample for which we observe parental attributes in the year prior to children's transition to secondary education. This analysis confirmed the empirical pattern that we find when using the full cross-sectional sample of the Microcensus.

We hope that our descriptive account of the prevalence of non-standard employment in households with children in Germany and its association with children's educational attainment will inspire future research on the implications of changing labor market structures for the intergenerational transmission of social (dis-)advantage and equality of opportunity in society. One fruitful avenue for future research could be to investigate the individual-level mechanisms that account for the association between parents' non-standard employment and children's educational 
attainment. More specifically, it would be important to disentangle the role of parental time with children, as well as parents' physical and psychological health as potential factors mediating this association. This could be done with detailed household-level time use data. It would also be of interest to investigate in further depth our finding that particularly mothers' fixed-term employment and non-standard work schedules are associated with lower educational chances of their children, and whether this finding is specific to Germany or also holds in other societal contexts. Future research could investigate how the prevalence of non-standard employment in households with children and its association with children's educational chances differs across societies. Given Germany's dual labor market structure and its stratified educational system and social protection system, educational inequality between children with parents in non-standard employment and children with parents in standard employment could be expected to be particularly high in Germany.

Our study on the implications of parental non-standard employment and children's educational chances shines a spotlight on what is likely to become an increasingly important challenge for policy makers to address. In the wake of the COVID-19 pandemic and its aftermath, fixed-term contracts and non-standard work schedules will likely increase. More specifically, the demand for labor is likely to grow in sectors where non-standard schedules are common, such as the medical and care sector. Facing an increasing level of uncertainty, employers may be more inclined to hire employees on fixed-term contracts. Moreover, the dramatic increase in remote working during the pandemic may lead to a further blending of work and private life and accelerate the rise of non-standard work schedules, with uncertain consequences for the psychological and physical health of workers and their children. Researchers and policy makers should pay close attention to the downstream effects of changing labor markets - and particularly the rise in fixedterm employment and non-standard work schedules — on the educational and life chances of children and the intergenerational transmission of social disadvantage. 


\section{Notes}

${ }^{1}$ For a comprehensive review of this literature see Li et al. (2014).

${ }^{2}$ Microcensus 2008-15 Scientific Use Files (SUF); DOI: 10.21242/12211.2008.00.00.3.1.0;

10.21242/12211.2009.00.00.3.1.0; 10.21242/12211.2010.00.00.3.1.0; 10.21242/12211.2011.00.00.3.1.0;

10.21242/12211.2012.00.00.3.1.0; 10.21242/12211.2013.00.00.3.1.0; 10.21242/12211.2014.00.00.3.1.0;

10.21242/12211.2015.00.00.3.1.0; own calculations.

${ }^{3}$ Our definition of parents refers to co-resident parents, including step-parents. Moreover, given the small number of same-sex couples with children in our samples $(\mathrm{N}=36)$, we ar unable to examine the prevalence and dynamics of nonstandard employment in these households.

${ }^{4}$ Since the German Microcensus does not provide information on the within-school track of children in the comprehensive school (Gesamtschule), we exclude these children from our analyses. In Germany about 11 percent of children attend comprehensive school (Statistisches Bundesamt, 2018).

5 We focus on evening, instead of night work, because $6 \mathrm{pm}-11 \mathrm{pm}$ is particularly important for parent-child interactions. Saturday work is chosen over Sunday work, because in Germany weekend work is tightly regulated by law, and if people work on the weekend, they far more often do so on Saturdays compared to Sundays. Moreover, the small proportion of people working on Sundays likely belong to a particularly selective group in terms of their occupation and industry.

${ }^{6}$ Table A2 in the Online Supplement shows the same distribution, but further differentiates between mothers and fathers with short fixed-term contracts of less than one year and longer fixed-term contracts. Note that the overall unemployment rate was very low in Germany in our observation years and particularly low in the demographic group of our study sample, parents of young teenage children. Households in our sample include single parent households. 7 Table A3 shows this distribution with the categories of 'regularly' and 'always' working during evenings separately.

${ }^{8}$ Table A4 shows this distribution with the categories of 'regularly' and 'always' working Saturdays separately.

9 This dichotomization is based on our observation that short fixed-term contracts are negatively associated with children's educational attainment, whilst there is no clear association between long fixed-term contracts and children's educational attainment, as discussed in further depth below.

${ }^{10}$ Linear probability models have been shown to yield essentially the same results as logistic regression models when the relative size of the outcome categories is balanced, with either response category containing between 20 percent and 80 percent of the observations (see Cox \& Wermuth, 1992). This applies to our sample, as roughly half of the respondents are in the academic track and half in the vocational track. Given that the coefficients of linear probability models can more readily be interpreted we therefore chose this approach over running logistic regressions.

${ }^{11}$ Note that the parents in our analysis sample had children during a family policy regime that very strongly favored male breadwinner arrangements before the child benefit reform of 2007 (Elterngeld) was implemented in Germany. The institutional context when their children were very young therefore strongly favored a traditional gendered division of labor that is likely to solidify as children grow older. 
Allmendinger, J., Hipp, L., and Stuth, S. (2013). Atypical employment in Europe 1996-2011. WZB Discussion Paper.

Allmendinger, J., Jahn, K., Promberger, M., Schels, B., and Stuth, S. (2018). Prekäre Beschäftigung und unsichere Haushaltslagen im Lebensverlauf. WSI-Mitteilungen, 71(4), 259_ 269.

Artazcoz, L., Benach, J., Borrell, C., and Cortès, I. (2005). Social inequalities in the impact of flexible employment on different domains of psychosocial health. Journal of Epidemiology \& Community Health, 59(9), 761-767.

Barlow, J., and Axford, N. (2014). Giving children a better start in life: From science to policy and practice. Journal of Children's Services.

Barone, C., Chambuleyron, E., Vonnak, R., and Assirelli, G. (2019). Home-based shared book reading interventions and children's language skills: A meta-analysis of randomised controlled trials. Educational Research and Evaluation, 25(5-6), 270-298.

Benach, J., Vives, A., Amable, M., Vanroelen, C., Tarafa, G., and Muntaner, C. (2014). Precarious employment: Understanding an emerging social determinant of health. Annual Review of Public Health, 35.

Betthäuser, B. (2017). Protecting outsiders? Corporatism and the dualisation of unemployment protection in Germany and Austria. European Journal of Social Security, 19(3), 209-224.

BFSFJ. (2015). Familienbilder in Deutschland und Frankreich. Monitor Familienforschung, 34.

Bianchi, S. M. (2000). Maternal employment and time with children: Dramatic change or surprising continuity? Demography, 37(4), 401-414.

Brady, D., and Biegert, T. (2017). The Rise of Precarious Employment in Germany. In Research in the Sociology of Work: Vol. 31. Precarious Work (Vol. 31, pp. 245-271). Emerald Publishing Limited.

Bratti, M., and Mendola, M. (2014). Parental health and child schooling. Journal of Health Economics, 35, 94-108.

Breen, R., and Müller, W. (2020). Education and intergenerational social mobility in Europe and the United States. Stanford University Press.

Brooks-Gunn, J., Brown, B., Duncan, G. J., and Moore, K. A. (1995). Child development in the context of family and community resources. Washington, DC: The National Academy of Sciences.

Buchholz, S., and Schier, A. (2015). New game, new chance? Social inequalities and upgrading secondary school qualifications in West Germany. European Sociological Review, 31(5), 603615.

Bukodi, E., and Goldthorpe, J. H. (2018). Social mobility and education in Britain. Cambridge: Cambridge University Press.

Chait Barnett, R., Gareis, K. C., and Brennan, R. T. (2008). Wives' Shift Work Schedules and Husbands' and Wives' Well-Being in Dual-Earner Couples With Children. Journal of Family Issues, 29(3), 396-422.

Champion, S., Rumbold, A., Steele, E., Giles, L., Davies, M., and Moore, V. (2012). Parental work schedules and child overweight and obesity. International Journal of Obesity, 36(4), 573 580 .

Costa, G., and Sartori, S. (2005). Flexible work hours, ageing and well-being. International Congress Series, 1280, 23-28. Elsevier. 
Davis, K. D., Benjamin Goodman, W., Pirretti, A. E., and Almeida, D. M. (2008). Nonstandard Work Schedules, Perceived Family Well-Being, and Daily Stressors. Journal of Marriage and Family, 70(4), 991-1003.

Davis, K. D., Crouter, A. C., and McHale, S. M. (2006). Implications of Shift Work for ParentAdolescent Relationships in Dual-Earner Families. Family Relations, 55(4), 450-460.

De Graaf, N. D., De Graaf, P. M., and Kraaykamp, G. (2000). Parental cultural capital and educational attainment in the Netherlands. Sociology of Education, 92-111.

Duncan, G. J., and Brooks-Gunn, J. (1997). Consequences of Growing Up Poor. New York: Russell Sage Foundation.

Dunifon, R., Kalil, A., Crosby, D. A., and Su, J. H. (2013). Mothers' night work and children's behavior problems. Developmental Psychology, 49(10), 1874-1885.

Emmenegger, P., Häusermann, S., Palier, B., and Seeleib-Kaiser, M. (2012). The age of dualization. Oxford; New York: Oxford University Press.

Farkas, G. (2003). Cognitive skills and noncognitive traits and behaviors in stratification processes. Annual Review of Sociology, 29(1), 541-562.

Gash, V., and Inanc, H. (2013). Insecurity and the Peripheral Workforce. In D. Gallie (Ed.), Economic Crisis, Quality of Work, and Social Integration. Oxford University Press.

Gerring, J. (2016). Case study research: Principles and practices. Cambridge: Cambridge University Press.

Gracia, P., and García-Román, J. (2018). Child and Adolescent Developmental Activities and Time Use in Spain: The Gendered Role of Parents' Work Schedules and Education Levels. European Sociological Review, 34(5), 518-538.

Green, F. (2015). Health effects of job insecurity. IZA World of Labor.

Han, W.-J. (2005). Maternal nonstandard work schedules and child cognitive outcomes. Child Development, 76(1), 137-154.

Han, W.-J. (2008). Shift work and child behavioral outcomes. Work, Employment and Society, 22(1), $67-87$.

Han, W.-J., and Fox, L. E. (2011). Parental Work Schedules and Children's Cognitive Trajectories. Journal of Marriage and the Family, 73(5), 962-980.

Han, W.-J., and Miller, D. P. (2009). Parental Work Schedules and Adolescent Depression. Health Sociology Review: The Journal of the Health Section of the Australian Sociological Association, 18(1), 36-49.

Han, W.-J., Miller, D. P., and Waldfogel, J. (2010). Parental work schedules and adolescent risky behaviors. Developmental Psychology, 46(5), 1245-1267.

Hao, L., and Yeung, W.-J. J. (2015). Parental spending on school-age children: Structural stratification and parental expectation. Demography, 52(3), 835-860.

Harknett, K., Schneider, D., and Luhr, S. (2020). Who Cares if Parents have Unpredictable Work Schedules? Just-in-Time Work Schedules and Child Care Arrangements. Social Problems.

Harrington, J. M. (2001). Health effects of shift work and extended hours of work. Occupational and Environmental Medicine, 58(1), 68-72.

Henly, J. R., and Lambert, S. J. (2014). Unpredictable work timing in retail jobs: Implications for employee work-life conflict. ILR Review, 67(3), 986-1016.

Hsin, A., and Felfe, C. (2014). When does time matter? Maternal employment, children's time with parents, and child development. Demography, 51(5), 1867-1894. 
ILO. (2018). Women and Men in the Informal Economy: A Statistical Picture. Geneva: International Labour Organisation.

Inanc, H. (2020). Varieties of Precarity: How Insecure Work Manifests Itself, Affects WellBeing, and Is Shaped by Social Welfare Institutions and Labor Market Policies. Work and Occupations, 47(4), 504-511.

Kaiser, T., Li, J., and Pollmann-Schult, M. (2019). Evening and night work schedules and children's social and emotional well-being. Community, Work \& Family, 22(2), 167-182.

Kalil, A., Ziol-Guest, K. M., and Levin Epstein, J. (2010). Nonstandard Work and Marital Instability: Evidence From the National Longitudinal Survey of Youth. Journal of Marriage and Family, 72(5), 1289-1300.

Kalleberg, A. L. (2009). Precarious work, insecure workers: Employment relations in transition. American Sociological Review, 74(1), 1-22.

Kalleberg, A. L. (2011). Good jobs, bad jobs: The rise of polarized and precarious employment systems in the United States, 1970s-2000s. Russell Sage Foundation.

Kalleberg, A. L. (2018). Precarious lives: Job insecurity and well-being in rich democracies. Cambridge, UK; Medford, MA: Polity Press.

Kalleberg, A. L., Reskin, B. F., and Hudson, K. (2000). Bad jobs in America: Standard and nonstandard employment relations and job quality in the United States. American Sociological Review, 256-278.

Kantermann, T., Juda, M., Vetter, C., and Roenneberg, T. (2010). Shift-work research: Where do we stand, where should we go? Sleep and Biological Rhythms, 8(2), 95-105.

Kaushal, N. K., Magnuson, K., and Waldfogel, J. (2011). How Is Family Income Related to Investments in Children's Learning? In G. J. Duncan and R. J. Murnane (Eds.), Whither opportunity?: Rising inequality, schools, and children's life chances (pp. 187-206). New York: Russell Sage Foundation.

Lareau, A. (2003). Unequal childhoods: Class, race, and family life. Berkeley: University of California Press.

Li, J., Johnson, S. E., Han, W.-J., Andrews, S., Kendall, G., Strazdins, L., and Dockery, A. (2014). Parents' nonstandard work schedules and child well-being: A critical review of the literature. The Journal of Primary Prevention, 35(1), 53-73.

Li, J., Kaiser, T., Pollmann-Schult, M., and Strazdins, L. (2019). Long work hours of mothers and fathers are linked to increased risk for overweight and obesity among preschool children. Journal of Epidemiology and Community Health, 73(8), 723-729.

Liu, H., Wang, Q., Keesler, V., and Schneider, B. (2011). Non-standard work schedules, workfamily conflict and parental well-being. Social Science Research, 40(2), 473-484.

Major, L. E., and Machin, S. (2018). Social Mobility: And Its Enemies. Penguin UK.

McGovern, P., Smeaton, D., and Hill, S. (2004). Bad Jobs in Britain: Nonstandard Employment and Job Quality. Work and Occupations, 31(2), 225-249.

Miller, D. P., and Han, W.-J. (2008). Maternal nonstandard work schedules and adolescent overweight. American Journal of Public Health, 98(8), 1495-1502.

Mindell, J. A., and Williamson, A. A. (2018). Benefits of a bedtime routine in young children. Sleep Medicine Reviews, 40, 93-108.

Müller, W., and Pollak, R. (2010). Weshalb gibt es so wenige Arbeiterkinder in Deutschlands Universitäten? In R. Becker and W. Lauterbach (Eds.), Bildung als Privileg: Ursachen, 
Mechanismen, Prozesse und Wirkungen (pp. 303-342). Wiesbaden: VS Verlag für Sozialwissenschaften.

Müller, W., Steinmann, S., and Ell, R. (1998). Education and labour market entry in Germany. In Y. Shavit and W. Müller (Eds.), From school to work: A comparative study of educational qualifications and occupational destinations (pp. 143-188). Oxford: Oxford University Press.

Murray, L., Woolgar, M., Martins, C., Christaki, A., Hipwell, A., and Cooper, P. (2006). Conversations around homework: Links to parental mental health, family characteristics and child psychological functioning. British Journal of Developmental Psychology, 24(1), 125-149.

Nolan, J. P., Wichert, I. C., and Burchell, B. J. (2000). Job insecurity, psychological well-being and family life. Oxford: Routledge.

OECD. (2020). Fixed-term Employment (indicator). https://doi.org/10.1787/75589b8a-en

Perry-Jenkins, M., Goldberg, A. E., Pierce, C. P., and Sayer, A. G. (2007). Shift Work, Role Overload, and the Transition to Parenthood. Journal of Marriage and Family, 69(1), 123-138.

Presser, H. B. (2005). Working in a 24/ 7 Economy: Challenges for American Families. Russell Sage Foundation.

Reardon, S. F. (2011). The widening academic achievement gap between the rich and the poor: New evidence and possible explanations. In G. J. Duncan and R. J. Murnane (Eds.), Whither opportunity (pp. 91-116). New York: Russell Sage Foundation Press.

Rose, D., and Harrison, E. (Eds.). (2010). Social class in Europe: An introduction to the European Socioeconomic Classification. London: Routledge.

Schneider, D., and Harknett, K. (2019). Consequences of Routine Work-Schedule Instability for Worker Health and Well-Being. American Sociological Review, 0003122418823184.

Schober, P. S., and Zoch, G. (2019). Change in the gender division of domestic work after mothers or fathers took leave. European Societies, 21(1), 158-180.

Standing, G. (2011). The Precariat: The New Dangerous Class. A\&amp;C Black.

Statistisches Bundesamt. (2018). Schulen auf einen Blick. Berlin: Statistisches Bundesamt.

Strazdins, L., Clements, M. S., Korda, R. J., Broom, D. H., and D’Souza, R. M. (2006). Unsociable Work? Nonstandard Work Schedules, Family Relationships, and Children's Well-Being. Journal of Marriage and Family, 68(2), 394-410. JSTOR. Retrieved from JSTOR.

Täht, K., and Mills, M. (2012). Nonstandard Work Schedules, Couple Desynchronization, and Parent-Child Interaction. Journal of Family Issues, 33(8), 1054-1087.

Totterdell, P. (2005). Work schedules. In J. B. Barling, E. K. Kelloway, and M. R. Frone (Eds.), Handbook of work stress. California: Sage Publications.

Trappe, H., Pollmann-Schult, M., and Schmitt, C. (2015). The rise and decline of the male breadwinner model. European Sociological Review, 31(2), 230-242.

Virtanen, M., Kivimäki, M., Joensuu, M., Virtanen, P., Elovainio, M., and Vahtera, J. (2005). Temporary employment and health: A review. International Journal of Epidemiology, 34(3), 610 622.

Vogel, M., Braungardt, T., Meyer, W., and Schneider, W. (2012). The effects of shift work on physical and mental health. Journal of Neural Transmission, 119(10), 1121-1132.

Wight, V. R., Raley, S. B., and Bianchi, S. M. (2008). Time for children, one's spouse and oneself among parents who work nonstandard hours. Social Forces, 87(1), 243-271.

Zhao, Y., Richardson, A., Poyser, C., Butterworth, P., Strazdins, L., and Leach, L. S. (2019). Shift work and mental health: A systematic review and meta-analysis. International Archives of Occupational and Environmental Health. 
Zoch, G., Bächmann, A.-C., and Vicari, B. (2020). Who cares when care closes? Carearrangements and parental working conditions during the COVID-19 pandemic in Germany. European Societies, 1-13. 
Table 1. Parental school qualification, professional qualification and social class

\begin{tabular}{|c|c|c|c|c|c|}
\hline & & \multicolumn{2}{|c|}{ Mother } & \multicolumn{2}{|c|}{ Father } \\
\hline & & Percent & $N$ & Percent & $N$ \\
\hline \multicolumn{6}{|l|}{ School-leaving qualifiaction } \\
\hline 1. Lower secondary or less & & 34,96 & 21946 & 40,46 & 22069 \\
\hline 2. Mid-secondary & & 33,84 & 21241 & 22,49 & 12268 \\
\hline 3. Secondary (vocational) & & 6,09 & 3825 & 9,71 & 5296 \\
\hline 4. Secondary (academic) & & 25,10 & 15758 & 27,35 & 14918 \\
\hline missing & & - & 1390 & - & 9609 \\
\hline \multicolumn{6}{|l|}{ Professional qualifiaction } \\
\hline 1. None & & 18,84 & 11827 & 12,47 & 6800 \\
\hline 2. Secondary vocational & & 59,76 & 37510 & 50,16 & 27360 \\
\hline 4. Postseconday vocational & & 4,00 & 2511 & 10,62 & 5792 \\
\hline 5. Tertiary applied & & 6,42 & 4028 & 11,49 & 6268 \\
\hline 6. Tertiary academic & & 10,98 & 6893 & 15,26 & 8326 \\
\hline missing & & - & 1391 & - & 9614 \\
\hline \multicolumn{6}{|l|}{ Parental class } \\
\hline 1. Higher salariat & & 24,59 & 13351 & 11,80 & 6972 \\
\hline 2. Lower salariat & & 19,03 & 10333 & 18,66 & 11029 \\
\hline 3. Higher white collar & & 5,18 & 2811 & 22,94 & 13560 \\
\hline 4. Petite bourgeois & & 5,34 & 2901 & 3,47 & 2048 \\
\hline 5. Small farmers & & 0,63 & 340 & 0,36 & 213 \\
\hline 6. Higher grade blue collar & & 4,71 & 2557 & 1,58 & 934 \\
\hline 7. Lower white collar & & 7,38 & 4006 & 21,69 & 12817 \\
\hline 8. Skilled manual & & 19,53 & 10607 & 3,31 & 1955 \\
\hline 9. Semi-/non-skilled & & 13,62 & 7396 & 16,20 & 9574 \\
\hline \multirow[t]{2}{*}{ missing } & & - & 9858 & - & 5058 \\
\hline & Total & 100,00 & 64160 & 100,00 & 64160 \\
\hline
\end{tabular}


Table 2. Percentage of children by mothers' and fathers' employment status

\begin{tabular}{|c|c|c|c|c|c|c|c|}
\hline \multirow[b]{2}{*}{ Father } & \multicolumn{7}{|c|}{ Mother } \\
\hline & $\begin{array}{c}\text { Employer / } \\
\text { self- } \\
\text { employed } \\
\end{array}$ & $\begin{array}{c}\text { Permanent } \\
\text { contract }\end{array}$ & $\begin{array}{c}\text { Fixed-term } \\
\text { contract }\end{array}$ & $\begin{array}{l}\text { Unem- } \\
\text { ployed }\end{array}$ & Inactive & $\begin{array}{c}\text { Not in } \\
\text { household }\end{array}$ & Total \\
\hline Employer / self-employed & $1,56 \%$ & $7,68 \%$ & $0,34 \%$ & $0,03 \%$ & $1,93 \%$ & $0,35 \%$ & $11,88 \%$ \\
\hline Permanent contract & $3,63 \%$ & $41,19 \%$ & $2,84 \%$ & $0,21 \%$ & $15,51 \%$ & $1,32 \%$ & $64,69 \%$ \\
\hline Fixed-term contract & $0,12 \%$ & $1,22 \%$ & $0,33 \%$ & $0,03 \%$ & $0,76 \%$ & $0,07 \%$ & $2,53 \%$ \\
\hline Unemployed & $0,01 \%$ & $0,07 \%$ & $0,01 \%$ & $0,07 \%$ & $0,14 \%$ & $0,02 \%$ & $0,31 \%$ \\
\hline Inactive & $0,22 \%$ & $2,21 \%$ & $0,30 \%$ & $0,10 \%$ & $2,49 \%$ & $0,33 \%$ & $5,65 \%$ \\
\hline Not in household & $1,01 \%$ & $9,11 \%$ & $1,40 \%$ & $0,30 \%$ & $3,12 \%$ & $0,00 \%$ & $14,93 \%$ \\
\hline Total & $6,54 \%$ & $61,48 \%$ & $5,22 \%$ & $0,72 \%$ & $23,94 \%$ & $2,10 \%$ & $100,00 \%$ \\
\hline
\end{tabular}

Note: Darker shades mark mothers and fathers in fixed-term employment; $\mathrm{N}=64,160$

Table 3. Percentage of children by mothers' and fathers' frequency of working during evenings (6pm-11pm)

\begin{tabular}{|c|c|c|c|c|c|c|c|}
\hline \multirow[b]{2}{*}{ Father } & \multicolumn{7}{|c|}{ Mother } \\
\hline & Never & Sometimes & Reg/Always & Unemployed & Inactive & Not in $\mathrm{HH}$ & Total \\
\hline Never & $19,33 \%$ & $2,54 \%$ & $4,24 \%$ & $0,12 \%$ & $7,99 \%$ & $0,83 \%$ & $35,06 \%$ \\
\hline Sometimes & $8,68 \%$ & $3,44 \%$ & $2,20 \%$ & $0,05 \%$ & $4,25 \%$ & $0,45 \%$ & $19,08 \%$ \\
\hline Regularly/Always & $10,96 \%$ & $2,52 \%$ & $4,99 \%$ & $0,09 \%$ & $5,95 \%$ & $0,46 \%$ & $24,97 \%$ \\
\hline Unemployed & $0,05 \%$ & $0,02 \%$ & $0,02 \%$ & $0,07 \%$ & $0,14 \%$ & $0,02 \%$ & $0,31 \%$ \\
\hline Inactive & $1,60 \%$ & $0,44 \%$ & $0,68 \%$ & $0,10 \%$ & $2,49 \%$ & $0,33 \%$ & $5,65 \%$ \\
\hline Not in household & $6,83 \%$ & $1,98 \%$ & $2,71 \%$ & $0,30 \%$ & $3,12 \%$ & $0,00 \%$ & $14,93 \%$ \\
\hline Total & $47,46 \%$ & $10,94 \%$ & $14,83 \%$ & $0,72 \%$ & $23,94 \%$ & $2,10 \%$ & $100,00 \%$ \\
\hline
\end{tabular}

Note : Darker shades mark mothers and fathers who regularly or always work in the evening; $N=64,160$

Table 4. Percentage of children by mothers' and fathers' frequency of working on Saturdays

\begin{tabular}{|c|c|c|c|c|c|c|c|}
\hline \multirow[b]{2}{*}{ Father } & \multicolumn{7}{|c|}{ Mother } \\
\hline & Never & Sometimes & Reg/Always & Unemployed & Inactive & Not in $\mathrm{HH}$ & Total \\
\hline Never & $18,97 \%$ & $3,69 \%$ & $5,58 \%$ & $0,13 \%$ & $8,80 \%$ & $0,82 \%$ & $37,99 \%$ \\
\hline Sometimes & $8,83 \%$ & $3,77 \%$ & $3,16 \%$ & $0,07 \%$ & $4,97 \%$ & $0,50 \%$ & $21,31 \%$ \\
\hline Regularly/Always & $7,55 \%$ & $2,21 \%$ & $5,15 \%$ & $0,06 \%$ & $4,43 \%$ & $0,43 \%$ & $19,81 \%$ \\
\hline Unemployed & $0,05 \%$ & $0,01 \%$ & $0,02 \%$ & $0,07 \%$ & $0,14 \%$ & $0,02 \%$ & $0,31 \%$ \\
\hline Inactive & $1,46 \%$ & $0,48 \%$ & $0,79 \%$ & $0,10 \%$ & $2,49 \%$ & $0,33 \%$ & $5,65 \%$ \\
\hline Not in household & $6,26 \%$ & $2,01 \%$ & $3,24 \%$ & $0,30 \%$ & $3,12 \%$ & $0,00 \%$ & $14,93 \%$ \\
\hline Total & $43,11 \%$ & $12,17 \%$ & $17,94 \%$ & $0,72 \%$ & $23,94 \%$ & $2,10 \%$ & $100,00 \%$ \\
\hline
\end{tabular}


Figure 1. Distribution of monthly net household income

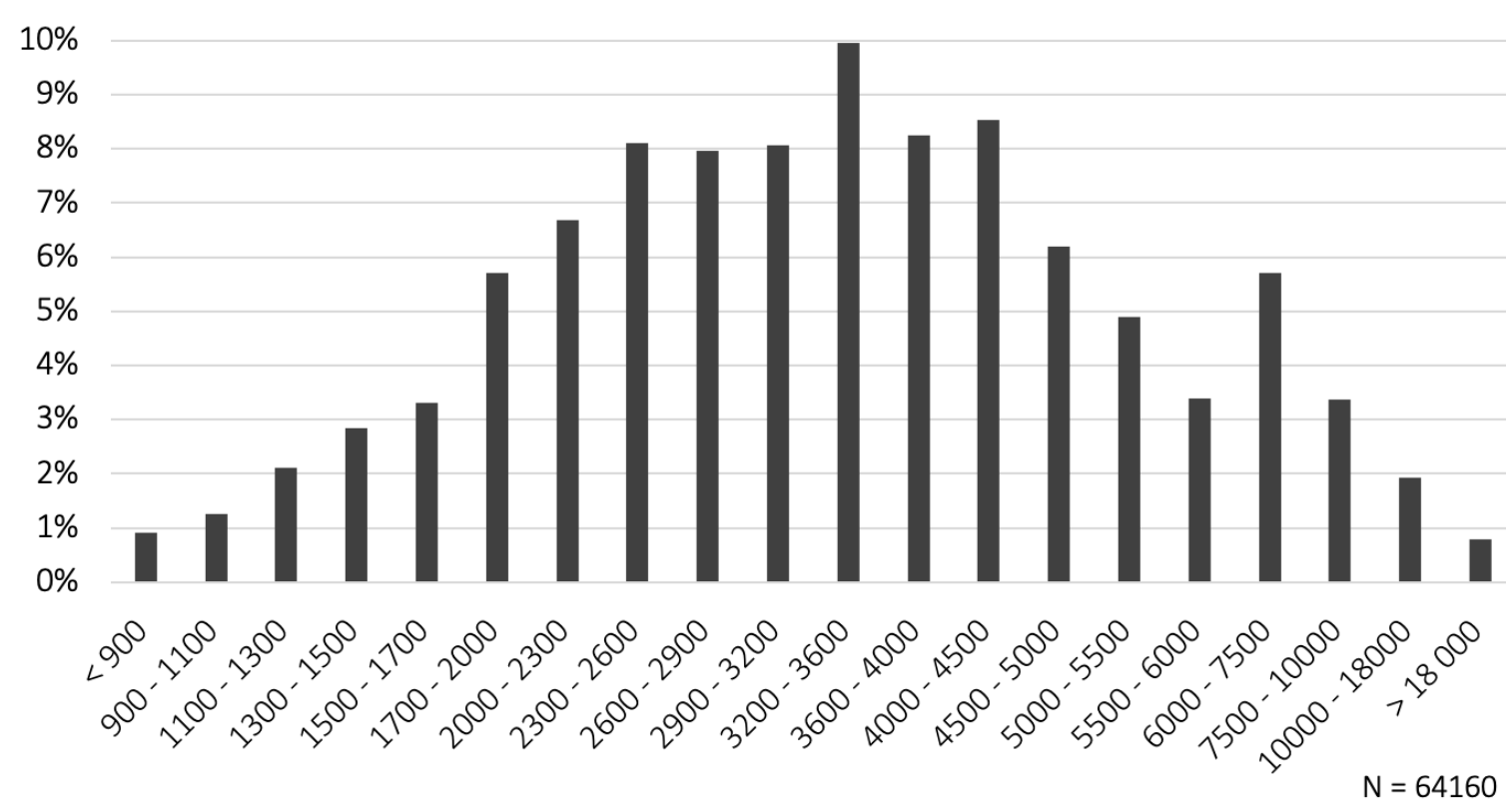


Figure 2. Concentration of fixed-term employment and non-standard work schedules in different household types

\begin{tabular}{|c|c|c|c|c|c|c|}
\hline \multirow[b]{2}{*}{ Type } & \multicolumn{2}{|c|}{ Mother } & \multicolumn{2}{|c|}{ Father } & \multirow{2}{*}{\multicolumn{2}{|c|}{$\begin{array}{c}\text { Proportion of children living in } \\
\text { household type }\end{array}$}} \\
\hline & $\begin{array}{l}\text { Evening and } \\
\text { Saturday work }\end{array}$ & $\begin{array}{l}\text { Short fixed- } \\
\text { term contract }\end{array}$ & $\begin{array}{l}\text { Evening and } \\
\text { Saturday work }\end{array}$ & $\begin{array}{l}\text { Short fixed- } \\
\text { term contract }\end{array}$ & & \\
\hline 1 & $x$ & $x$ & $x$ & $x$ & $25,61 \%$ & \\
\hline 2 & $x$ & $x$ & $\checkmark$ & $x$ & $13,57 \%$ & ש \\
\hline 3 & \multicolumn{2}{|c|}{ not employed } & $x$ & $x$ & $10,72 \%$ & 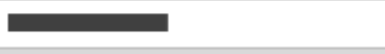 \\
\hline 4 & $\checkmark$ & $x$ & $\checkmark$ & $x$ & $8,25 \%$ & 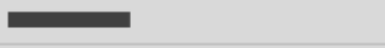 \\
\hline 5 & $\checkmark$ & $x$ & $x$ & $x$ & $8,17 \%$ & 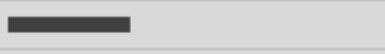 \\
\hline 6 & \multicolumn{2}{|c|}{ not employed } & $\checkmark$ & $x$ & $7,25 \%$ & 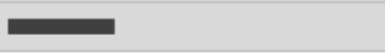 \\
\hline 7 & $x$ & $x$ & \multicolumn{2}{|c|}{ not in household } & $6,87 \%$ & ש \\
\hline 8 & $\checkmark$ & $x$ & \multicolumn{2}{|c|}{ not in household } & $3,67 \%$ & 正 \\
\hline 9 & \multicolumn{2}{|c|}{ not employed } & \multicolumn{2}{|c|}{ not in household } & $3,42 \%$ & 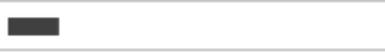 \\
\hline 10 & \multicolumn{2}{|c|}{ not employed } & \multicolumn{2}{|c|}{ not employed } & $2,79 \%$ & 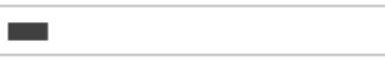 \\
\hline 11 & $x$ & $x$ & \multicolumn{2}{|c|}{ not employed } & $1,59 \%$ & - \\
\hline 12 & \multicolumn{2}{|c|}{ not in household } & $x$ & $x$ & $1,09 \%$ & - \\
\hline 13 & $\checkmark$ & $x$ & \multicolumn{2}{|c|}{ not employed } & $0,99 \%$ & घ \\
\hline 14 & $x$ & $\checkmark$ & $x$ & $x$ & $0,92 \%$ & - \\
\hline 15 & $x$ & $\checkmark$ & \multicolumn{2}{|c|}{ not in household } & $0,65 \%$ & $\mathbf{1}$ \\
\hline 16 & \multicolumn{2}{|c|}{ not in household } & $\checkmark$ & $x$ & $0,60 \%$ & I \\
\hline 17 & $x$ & $\checkmark$ & $\checkmark$ & $x$ & $0,53 \%$ । & I \\
\hline 18 & $\checkmark$ & $\checkmark$ & $x$ & $x$ & $0,41 \%$ । & $\mathbf{I}$ \\
\hline 19 & $\checkmark$ & $\checkmark$ & $\checkmark$ & $x$ & $0,38 \%$ । & I \\
\hline 20 & \multicolumn{2}{|c|}{ not in household } & \multicolumn{2}{|c|}{ not employed } & $0,36 \%$ । & $\mathbf{I}$ \\
\hline 21 & $x$ & $x$ & $x$ & $\checkmark$ & $0,33 \%$ । & 1 \\
\hline 22 & $\checkmark$ & $\checkmark$ & not in $h$ & ousehold & $0,32 \%$ । & $\mathbf{I}$ \\
\hline 23 & \multicolumn{2}{|c|}{ not employed } & $x$ & $\checkmark$ & $0,29 \%$ । & 1 \\
\hline 24 & $\checkmark$ & $x$ & $x$ & $\checkmark$ & $0,21 \%$ । & 1 \\
\hline 25 & \multicolumn{2}{|c|}{ not employed } & $\checkmark$ & $\checkmark$ & $0,20 \%$ । & । \\
\hline 26 & $x$ & $x$ & $\checkmark$ & $\checkmark$ & $0,19 \%$ । & । \\
\hline 27 & $\checkmark$ & $x$ & $\checkmark$ & $\checkmark$ & $0,16 \%$ । & 1 \\
\hline 28 & $x$ & $\checkmark$ & \multicolumn{2}{|c|}{ not employed } & $0,15 \%$ । & 1 \\
\hline 29 & $\checkmark$ & $\checkmark$ & \multicolumn{2}{|c|}{ not employed } & $0,08 \%$ । & । \\
\hline 30 & $x$ & $\checkmark$ & $x$ & $\checkmark$ & $0,07 \% \quad$ । & 1 \\
\hline 31 & $\checkmark$ & $\checkmark$ & $\checkmark$ & $\checkmark$ & $0,06 \% \quad$ । & 1 \\
\hline 32 & \multicolumn{2}{|c|}{ not in household } & $x$ & $\checkmark$ & $0,04 \%$ । & । \\
\hline 33 & $\checkmark$ & $\checkmark$ & $x$ & $\checkmark$ & $0,03 \%$ । & । \\
\hline 34 & $x$ & $\checkmark$ & $\checkmark$ & $\checkmark$ & $0,02 \%$ । & । \\
\hline 35 & \multicolumn{2}{|c|}{ not in household } & $\checkmark$ & $\checkmark$ & $0,02 \%$ । & । \\
\hline
\end{tabular}

Notes: The first binary measure indicates whether or not mothers and fathers work regularly or always on evenings or Satursdays; The second binary measure indicates whether or not mothers and fathers are employed on a fixed-term contract of less than on year; The gray shade indicates households in wich one or both parents have a short fixed-term contract or a non-standard work schedule $(46 \%)$; The black bars indicates the incidence of the respective household type. 
Figure 3. Association between parental employment status and children's educational track

\begin{tabular}{|c|c|c|c|c|c|c|}
\hline Mother & Coefficient & \multicolumn{5}{|c|}{ Coefficient plot } \\
\hline 1. Employer/self-employed & 0.000 & \multicolumn{5}{|c|}{$\longmapsto \bullet$} \\
\hline 2. Permanent contract & (Ref.) & & & & & \\
\hline 3. Fixed-term contract (long) & -0.005 & & $\longmapsto$ & $\longrightarrow$ & & \\
\hline 4. Fixed-term contract (short) & -0.030 & & $\longmapsto \hookrightarrow$ & & & \\
\hline 5. Unemployed & -0.047 & $\vdash$ & $\bullet$ & & & \\
\hline 6. Inactive & -0.029 & & $\mapsto \bullet-1$ & & & \\
\hline \multicolumn{7}{|l|}{ Father } \\
\hline 1. Employer/self-employed & -0.008 & \multicolumn{5}{|c|}{$\longmapsto \vdash$} \\
\hline 2. Permanent contract & (Ref.) & & & & & \\
\hline 3. Fixed-term contract (long) & -0.014 & \multicolumn{2}{|r|}{$\longmapsto$} & $\longrightarrow$ & & \\
\hline 4. Fixed-term contract (short) & -0.011 & \multicolumn{2}{|r|}{$\longmapsto$} & $\longrightarrow$ & & \\
\hline 5. Unemployed & -0.054 & \multicolumn{2}{|c|}{$\longmapsto$} & -1 & & \\
\hline \multirow[t]{2}{*}{ 6. Inactive } & -0.022 & \multicolumn{2}{|r|}{$\longmapsto$} & & & \\
\hline & -0.15 & -0.10 & -0.05 & 00 & 0.05 & 0.10 \\
\hline
\end{tabular}

Figure 4. Association between parents' frequency of working evenings and children's educational track

\begin{tabular}{|c|c|c|c|c|c|c|}
\hline Mother & Coefficient & \multicolumn{5}{|c|}{ Coefficient plot } \\
\hline 1. Never & (Ref.) & & & & & \\
\hline 2. Sometimes & 0.003 & \multicolumn{5}{|c|}{$\mapsto-1$} \\
\hline 3. Regularly & -0.022 & \multicolumn{2}{|r|}{$\longmapsto \bullet$} & & & \\
\hline 4. Always & -0.036 & \multicolumn{2}{|r|}{$\longmapsto$} & & & \\
\hline \multicolumn{7}{|l|}{ Father } \\
\hline 1. Never & (Ref.) & & & & & \\
\hline 2. Sometimes & -0.004 & \multicolumn{5}{|c|}{$\mapsto \bullet$} \\
\hline 3. Regularly & 0.002 & \multicolumn{5}{|c|}{$\mapsto-1$} \\
\hline \multirow[t]{2}{*}{ 4. Always } & 0.003 & \multicolumn{5}{|c|}{$\longmapsto$} \\
\hline & -0.15 & -0.10 & -0.05 & .00 & 0.05 & 0.10 \\
\hline
\end{tabular}

Notes : Figure shows coefficients from model reported in Table A2; includes controls for net household income and mothers'and fathers' class and education; $95 \%$ Conifidence Intervals

Figure 5. Association between parents' frequency of working Saturdays and children's educational track

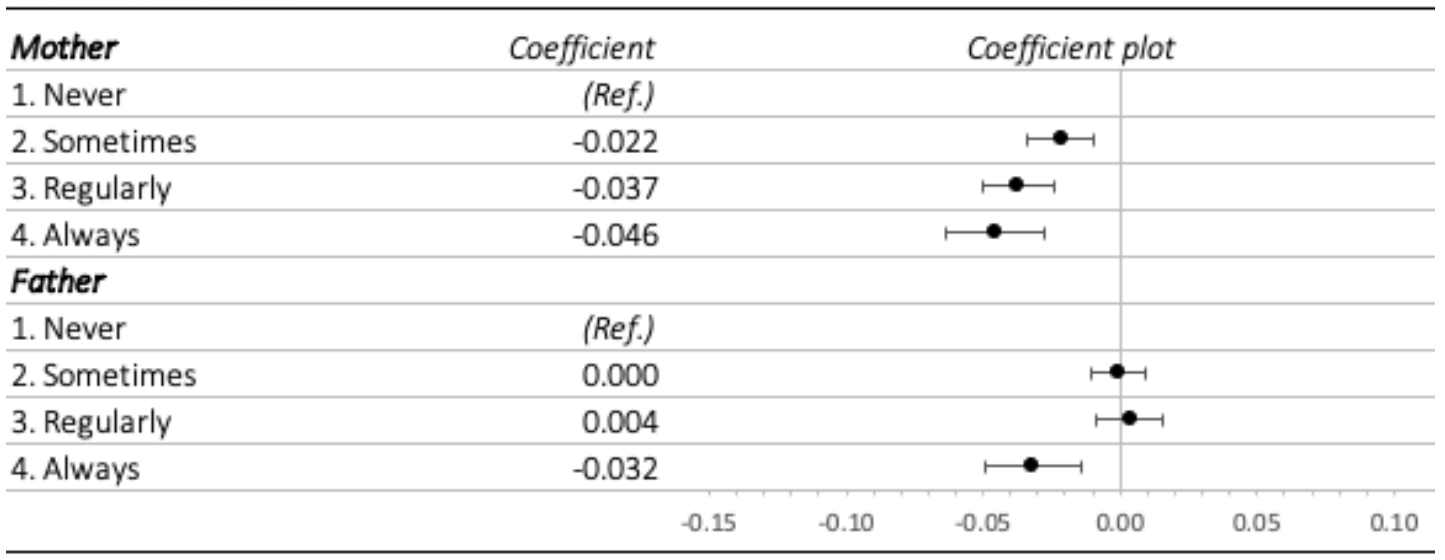

Notes : Figure shows coefficients from model reported in Table A2; includes controls for net household income and mothers'and fathers' class and education; $95 \%$ Conifidence Intervals 
Figure 6. Association between different household types and children's educational track (controlling for parental income, class and education)

\begin{tabular}{|c|c|c|c|c|c|c|c|}
\hline \multicolumn{2}{|c|}{ Mother } & \multicolumn{2}{|c|}{ Father } & \multirow[b]{2}{*}{ Share } & \multirow[b]{2}{*}{ Coeff. } & \multirow{2}{*}{\multicolumn{2}{|c|}{ Coefficient plot }} \\
\hline $\begin{array}{l}\text { Reg./always } \\
\text { work eve/sat }\end{array}$ & $\begin{array}{l}\text { Short fixed- } \\
\text { term contract }\end{array}$ & $\begin{array}{l}\text { Reg./always } \\
\text { work eve/sat }\end{array}$ & $\begin{array}{l}\text { Short fixed- } \\
\text { term contract }\end{array}$ & & & & \\
\hline$x$ & $x$ & $x$ & $x$ & $25,61 \%$ & (Ref.) & & \\
\hline$x$ & $x$ & $\checkmark$ & $x$ & $13,57 \%$ & 0,003 & \multicolumn{2}{|c|}{$\bullet$} \\
\hline \multicolumn{2}{|c|}{ not employed } & $x$ & $x$ & $10,72 \%$ & $-0,026$ & $\bullet$ & \\
\hline$\checkmark$ & $x$ & $\checkmark$ & $x$ & $8,25 \%$ & $-0,050$ & $\bullet$ & \\
\hline$\checkmark$ & $x$ & $x$ & $x$ & $8,17 \%$ & $-0,029$ & $\bullet$ & \\
\hline \multicolumn{2}{|c|}{ not employed } & $\checkmark$ & $x$ & $7,25 \%$ & $-0,038$ & $\bullet$ & \\
\hline$x$ & $x$ & \multicolumn{2}{|c|}{ not in household } & $6,87 \%$ & 0,047 & $\longmapsto$ & $\bullet$ \\
\hline$\checkmark$ & $x$ & \multicolumn{2}{|c|}{ not in household } & $3,67 \%$ & $-0,052$ & $\longmapsto$ & $\longrightarrow$ \\
\hline \multicolumn{2}{|c|}{ not employed } & \multicolumn{2}{|c|}{ not in household } & $3,42 \%$ & $-0,058$ & $\longmapsto$ & $\longrightarrow$ \\
\hline \multicolumn{2}{|c|}{ not employed } & \multicolumn{2}{|c|}{ not employed } & $2,79 \%$ & $-0,073$ & $\vdash \bullet-1$ & \\
\hline$x$ & $x$ & \multicolumn{2}{|c|}{ not employed } & $1,59 \%$ & $-0,018$ & $\vdash \bullet$ & -1 \\
\hline \multicolumn{2}{|c|}{ not in household } & $x$ & $x$ & $1,09 \%$ & $-0,089$ & $\longmapsto$ & $\longrightarrow$ \\
\hline$\checkmark$ & $x$ & \multicolumn{2}{|c|}{ not employed } & $0,99 \%$ & $-0,021$ & $\mapsto$ & -1 \\
\hline$x$ & $\checkmark$ & $x$ & $x$ & $0,92 \%$ & $-0,039$ & $\bullet-1$ & \\
\hline$x$ & $\checkmark$ & \multicolumn{2}{|c|}{ not in household } & $0,65 \%$ & $-0,032$ & $\bullet$ & \\
\hline \multicolumn{2}{|c|}{ not in household } & $\checkmark$ & $x$ & $0,60 \%$ & $-0,048$ & $\longmapsto$ & $\longrightarrow$ \\
\hline$x$ & $\checkmark$ & $\checkmark$ & $x$ & $0,53 \%$ & $-0,010$ & \multicolumn{2}{|c|}{$\longmapsto$} \\
\hline$\checkmark$ & $\checkmark$ & $x$ & $x$ & $0,41 \%$ & $-0,078$ & $\longmapsto$ & \\
\hline$\checkmark$ & $\checkmark$ & $\checkmark$ & $x$ & $0,38 \%$ & 0,008 & & $\bullet$ \\
\hline \multicolumn{2}{|c|}{ not in household } & \multicolumn{2}{|c|}{ not employed } & $0,36 \%$ & $-0,147$ & $\bullet$ & -1 \\
\hline$x$ & $x$ & $x$ & $\checkmark$ & $0,33 \%$ & $-0,016$ & $\longmapsto$ & $\longrightarrow$ \\
\hline$\checkmark$ & $\checkmark$ & \multicolumn{2}{|c|}{ not in household } & $0,32 \%$ & $-0,056$ & $\bullet$ & 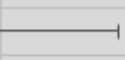 \\
\hline \multicolumn{2}{|c|}{ not employed } & $x$ & $\checkmark$ & $0,29 \%$ & $-0,005$ & $\longmapsto$ & $\longrightarrow$ \\
\hline$\checkmark$ & $x$ & $x$ & $\checkmark$ & $0,21 \%$ & $-0,014$ & $\longmapsto$ & $\longrightarrow$ \\
\hline \multicolumn{2}{|c|}{ not employed } & $\checkmark$ & $\checkmark$ & $0,20 \%$ & $-0,011$ & $\longmapsto$ & $\longrightarrow$ \\
\hline$x$ & $x$ & $\checkmark$ & $\checkmark$ & $0,19 \%$ & $-0,047$ & $\longmapsto \bullet$ & $\neg$ \\
\hline$\checkmark$ & $x$ & $\checkmark$ & $\checkmark$ & $0,16 \%$ & $-0,027$ & $\longmapsto$ & $\longrightarrow$ \\
\hline$x$ & $\checkmark$ & \multicolumn{2}{|c|}{ not employed } & $0,15 \%$ & 0,004 & $\longmapsto \bullet$ & $\longrightarrow$ \\
\hline$\checkmark$ & $\checkmark$ & note & mployed & $0,08 \%$ & $-0,150$ & $\longmapsto$ & \\
\hline$x$ & $\checkmark$ & $x$ & $\checkmark$ & $0,07 \%$ & $-0,088$ & $\longmapsto$ & $\longrightarrow$ \\
\hline$\checkmark$ & $\checkmark$ & $\checkmark$ & $\checkmark$ & $0,06 \%$ & $-0,163$ & $\longmapsto$ & \\
\hline not in & household & $x$ & $\checkmark$ & $0,04 \%$ & $-0,189$ & $\bullet$ & $\longrightarrow$ \\
\hline$\checkmark$ & $\checkmark$ & $x$ & $\checkmark$ & $0,03 \%$ & $-0,154$ & $\bullet$ & $\longrightarrow$ \\
\hline$x$ & $\checkmark$ & $\checkmark$ & $\checkmark$ & $0,02 \%$ & $-0,075$ & $\longmapsto$ & \\
\hline not in & household & $\checkmark$ & $\checkmark$ & $0,02 \%$ & 0,056 & $\longmapsto$ & $\bullet$ \\
\hline & & & & & $-0,40$ & $-0,20$ & 00 \\
\hline
\end{tabular}

Notes: Figure based on model shown in Table A3; including controls for parental income, class and education; 95\% Conifidence Intervals 
Table A1. Parental school qualification, professional qualification and social class (subsample of parents who were observed prior to children's transition to secondary education)

\begin{tabular}{|c|c|c|c|c|c|}
\hline & & \multicolumn{2}{|c|}{ Mother } & \multicolumn{2}{|c|}{ Father } \\
\hline & & Percent & $N$ & Percent & $N$ \\
\hline \multicolumn{6}{|l|}{ School-leaving qualifiaction } \\
\hline 1. Lower secondary or less & & 29.58 & 1674 & 36.35 & 1821 \\
\hline 2. Mid-secondary & & 32.89 & 1861 & 22.77 & 1141 \\
\hline 3. Secondary (vocational) & & 7.56 & 428 & 10.84 & 543 \\
\hline 4. Secondary (academic) & & 29.97 & 1696 & 30.04 & 1505 \\
\hline missing & & - & 89 & - & 738 \\
\hline \multicolumn{6}{|l|}{ Professional qualifiaction } \\
\hline 1. None & & 18.93 & 1071 & 13.53 & 678 \\
\hline 2. Secondary vocational & & 57.55 & 3257 & 47.78 & 2394 \\
\hline 4. Postseconday vocational & & 2.40 & 136 & 9.94 & 498 \\
\hline 5. Tertiary applied & & 7.60 & 430 & 12.12 & 607 \\
\hline 6. Tertiary academic & & 13.52 & 765 & 16.63 & 833 \\
\hline missing & & - & 89 & - & 738 \\
\hline \multicolumn{6}{|l|}{ Parental class } \\
\hline 1. Higher salariat & & 26.56 & 1326 & 15.81 & 840 \\
\hline 2. Lower salariat & & 20.23 & 1010 & 18.72 & 995 \\
\hline 3. Higher white collar & & 4.03 & 201 & 22.30 & 1185 \\
\hline 4. Petite bourgeois & & 4.53 & 226 & 3.50 & 186 \\
\hline 5. Small farmers & & 0.34 & 17 & 0.06 & 3 \\
\hline 6. Higher grade blue collar & & 6.45 & 322 & 1.52 & 81 \\
\hline 7. Lower white collar & & 8.99 & 449 & 22.60 & 1201 \\
\hline 8. Skilled manual & & 18.21 & 909 & 3.03 & 161 \\
\hline 9. Semi-/non-skilled & & 10.66 & 532 & 12.46 & 662 \\
\hline \multirow[t]{2}{*}{ missing } & & - & 756 & - & 434 \\
\hline & Total & 100.00 & 5748 & 100.00 & 5748 \\
\hline
\end{tabular}



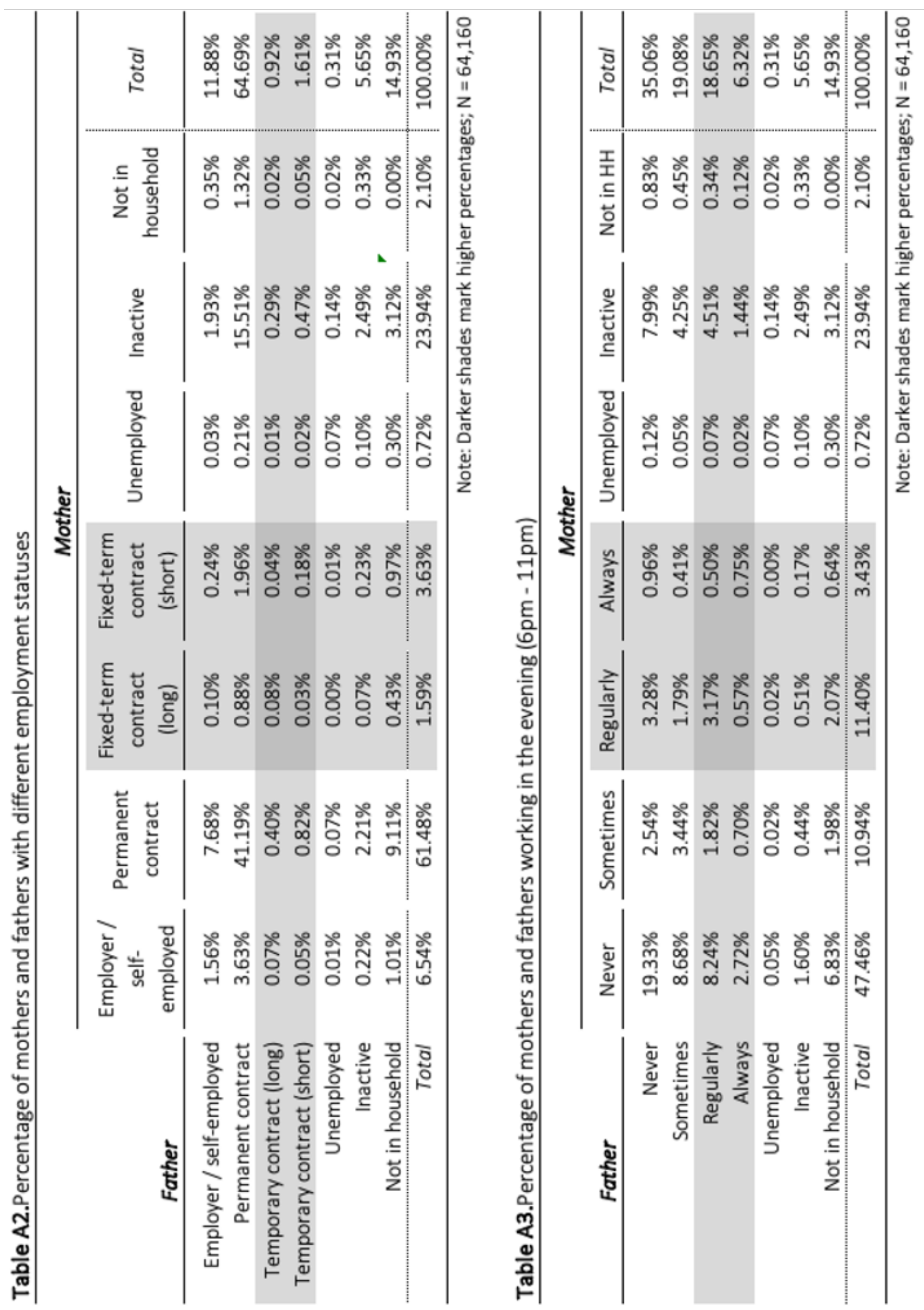


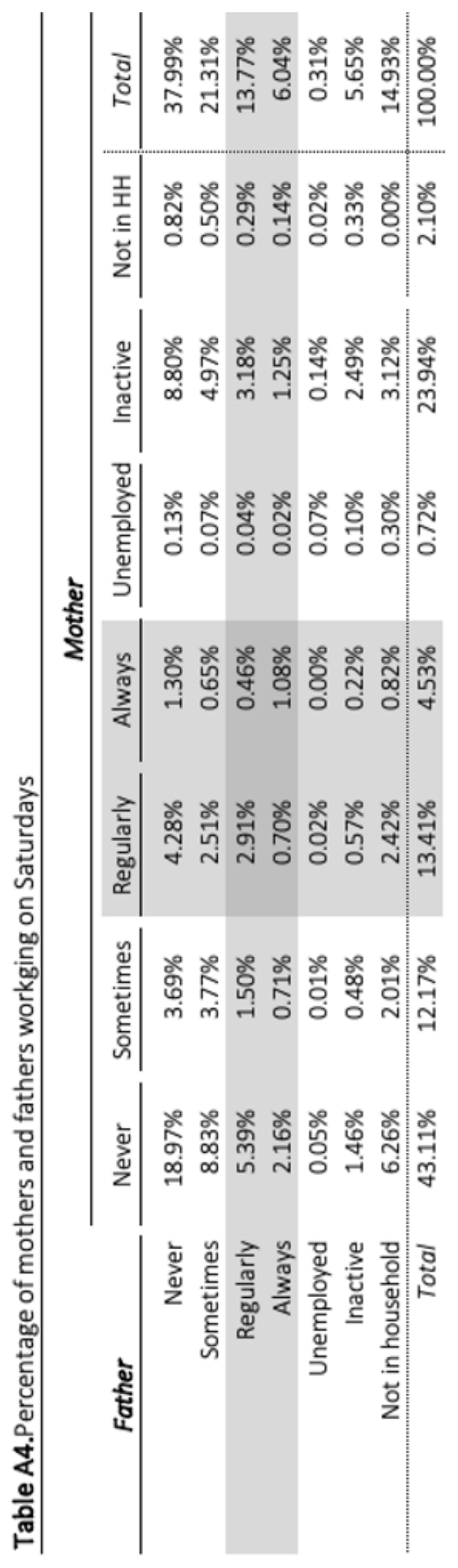


Table A5. Association between parental employment status and children's educational track

\begin{tabular}{|c|c|c|c|}
\hline & M2 & & M2 \\
\hline \multicolumn{2}{|l|}{ Mother employment status } & \multicolumn{2}{|l|}{ - continued - } \\
\hline 1. Employer / self-employed & -0.001 & Mother school qualification & \\
\hline 2. Permanent contract (Ref.) & & 1. Lower secondary or less & $-0.263^{* * *}$ \\
\hline 3. Fixed-term contract (long) & -0.004 & 2. Mid-secondary & $-0.181^{* * *}$ \\
\hline 4. Fixed-term contract (short) & $-0.032 * * *$ & 3. Upper sec. vocational) & $-0.086 * * *$ \\
\hline 5. Unemployed & $-0.046 *$ & \multicolumn{2}{|l|}{ 4. Uppper sec. academic (Ref.) } \\
\hline 6. Inactive & $-0.029 * * *$ & \multicolumn{2}{|l|}{ Father school qualification } \\
\hline 7. Not in the household & -0.093 & 1. Lower secondary or less & $-0.186 * * *$ \\
\hline Father employment status & & 2. Mid-secondary & $-0.118^{* * *}$ \\
\hline 1. Employer / self-employed & -0.008 & 3. Upper sec. vocational) & $-0.061^{* * *}$ \\
\hline 2. Permanent contract (Ref.) & \multicolumn{3}{|c|}{ 4. Uppper sec. academic (Ref.) } \\
\hline 3. Fixed-term contract (long) & -0.013 & \multicolumn{2}{|l|}{ Mother professional qualification } \\
\hline 4. Fixed-term contract (short) & -0.009 & 1. None & $-0.073^{* * *}$ \\
\hline 5. Unemployed & -0.056 & 2. Secondary vocational & $-0.034^{* * *}$ \\
\hline 6. Inactive & $-0.023 * *$ & 3. Post-secondary vocational & $0.038 * * *$ \\
\hline 7. Not in the household & 0.021 & 4. Tertiary vocational & -0.009 \\
\hline Net household income & $0.016^{* * *}$ & 5. Tertiary academic (Ref.) & \\
\hline \multicolumn{4}{|l|}{ Mother class } \\
\hline 1. Higher salariat (Ref.) & \multicolumn{3}{|c|}{ Father professional qualification } \\
\hline 2. Lower salariat & $-0.028 * * *$ & 1. None & $-0.062 * * *$ \\
\hline 3. Higher white collar & $-0.037 * * *$ & 2. Secondary vocational & $-0.074^{* * *}$ \\
\hline 4. Petite bourgeois & $-0.091 * * *$ & 3. Post-secondary vocational & $-0.053 * * *$ \\
\hline 5. Small farmers & $-0.209 * * *$ & 4. Tertiary vocational & $-0.037^{* * *}$ \\
\hline 6. Higher grade blue collar & $-0.060^{* * *}$ & 5. Tertiary academic (Ref.) & \\
\hline 7. Lower white collar & $-0.084^{* * *}$ & & \\
\hline 8. Skilled manual & $-0.132 * * *$ & & \\
\hline 9. Semi-/non-skilled & $-0.171^{* * *}$ & & \\
\hline \multicolumn{4}{|l|}{ Father class } \\
\hline \multicolumn{4}{|l|}{ 1. Higher salariat (Ref.) } \\
\hline 2. Lower salariat & $-0.015 *$ & & \\
\hline 3. Higher white collar & $-0.021 *$ & & \\
\hline 4. Petite bourgeois & $-0.043 * * *$ & & \\
\hline 5. Small farmers & $-0.102 * * *$ & & \\
\hline 6. Higher grade blue collar & $-0.033^{* * *}$ & & \\
\hline 7. Lower white collar & $-0.034^{* * *}$ & & \\
\hline 8. Skilled manual & $-0.080 * * *$ & & \\
\hline 9. Semi-/non-skilled & $-0.107 * * *$ & & \\
\hline
\end{tabular}


Table A6. Association between mothers' and fathers' work schedule and children's educational track

\begin{tabular}{|c|c|c|c|}
\hline Mother Saturday work & & Mother class & \\
\hline 1. Never (Ref.) & & 1. Higher salariat (Ref.) & \\
\hline 2. Sometimes & $-0.022 * * *$ & 2. Lower salariat & $-0.018^{*}$ \\
\hline 3. Regularly & $-0.038^{* * *}$ & 3. Higher white collar & $-0.039 * * *$ \\
\hline 4. Always & $-0.047^{* * *}$ & 4. Petite bourgeois & $-0.082 * * *$ \\
\hline Father Saturday work & & 5. Small farmers & $-0.193 * * *$ \\
\hline 1. Never (Ref.) & & 6. Higher grade blue collar & $-0.044 * *$ \\
\hline 2. Sometimes & -0.002 & 7. Lower white collar & $-0.073^{* * *}$ \\
\hline 3. Regularly & 0.003 & 8. Skilled manual & $-0.129 * * *$ \\
\hline 4. Always & $-0.034^{* * *}$ & 9. Semi-/non-skilled & $-0.165^{* * *}$ \\
\hline Mother evening work & & Father class & \\
\hline 1. Never (Ref.) & & 1. Higher salariat (Ref.) & \\
\hline 2. Sometimes & 0.005 & 2. Lower salariat & $-0.014^{*}$ \\
\hline 3. Regularly & $-0.021^{* *}$ & 3. Higher white collar & -0.016 \\
\hline 4. Always & $-0.035^{* * *}$ & 4. Petite bourgeois & $-0.032 * *$ \\
\hline Father evening work & & 5. Small farmers & $-0.089 * * *$ \\
\hline 1. Never (Ref.) & & 6. Higher grade blue collar & $-0.032 * *$ \\
\hline 2. Sometimes & -0.003 & 7. Lower white collar & $-0.031 * * *$ \\
\hline 3. Regularly & 0.002 & 8. Skilled manual & $-0.075^{* * *}$ \\
\hline 4. Always & 0.003 & 9. Semi-/non-skilled & $-0.100 * * *$ \\
\hline Mother employment status & & Mother school qualification & \\
\hline 1. Employer / self-employed & 0.007 & 1. Lower secondary or less & $-0.257^{* * *}$ \\
\hline 2. Permanent contract (Ref.) & & 2. Mid-secondary & $-0.179^{* * *}$ \\
\hline 3. Fixed-term contract (long) & 0.000 & 3. Upper sec. vocational) & $-0.085^{* * *}$ \\
\hline 4. Fixed-term contract (short) & $-0.029^{* *}$ & 4. Uppper sec. academic (Ref.) & \\
\hline 5. Unemployed & $-0.061 * *$ & Father school qualification & \\
\hline 6. Inactive & $-0.044^{* * *}$ & 1. Lower secondary or less & $-0.184^{* * *}$ \\
\hline 7. Not in the household & -0.110 & 2. Mid-secondary & $-0.117^{* * *}$ \\
\hline Father employment status & & 3. Upper sec. vocational) & $-0.061 * * *$ \\
\hline 1. Employer / self-employed & -0.003 & 4. Uppper sec. academic (Ref.) & \\
\hline 2. Permanent contract (Ref.) & & Mother professional qualification & \\
\hline 3. Fixed-term contract (long) & -0.011 & 1. None & $-0.073^{* * *}$ \\
\hline 4. Fixed-term contract (short) & -0.003 & 2. Secondary vocational & $-0.035^{* * *}$ \\
\hline 5. Unemployed & -0.054 & 3. Post-secondary vocational & $0.040^{* * *}$ \\
\hline 6. Inactive & $-0.019^{*}$ & 4. Tertiary vocational & -0.014 \\
\hline 7. Not in the household & 0.037 & 5. Tertiary academic (Ref.) & \\
\hline \multirow[t]{6}{*}{ Net household income } & $0.005^{* * *}$ & Father professional qualification & \\
\hline & & 1. None & $-0.059 * * *$ \\
\hline & & 2. Secondary vocational & $-0.072 * * *$ \\
\hline & & 3. Post-secondary vocational & $-0.052 * * *$ \\
\hline & & 4. Tertiary vocational & $-0.037^{* * *}$ \\
\hline & & 5. Tertiary academic (Ref.) & \\
\hline
\end{tabular}


Table A7. Association between household type and children's educational track

\begin{tabular}{|c|c|c|}
\hline Household type & 1 & (Ref.) \\
\hline Household type & 2 & 0.003 \\
\hline Household type & 3 & $-0.026^{* * *}$ \\
\hline Household type & 4 & $-0.050 * * *$ \\
\hline Household type & 5 & $-0.029^{* * *}$ \\
\hline Household type & 6 & $-0.038^{* * *}$ \\
\hline Household type & 7 & 0.047 \\
\hline Household type & 8 & -0.052 \\
\hline Household type & 9 & -0.058 \\
\hline Household type & 10 & $-0.073^{* * *}$ \\
\hline Household type & 11 & -0.018 \\
\hline Household type & 12 & -0.089 \\
\hline Household type & 13 & -0.021 \\
\hline Household type & 14 & $-0.039^{*}$ \\
\hline Household type & 15 & -0.032 \\
\hline Household type & 16 & -0.048 \\
\hline Household type & 17 & -0.010 \\
\hline Household type & 18 & $-0.078^{* *}$ \\
\hline Household type & 19 & 0.008 \\
\hline Household type & 20 & -0.147 \\
\hline Household type & 21 & -0.016 \\
\hline Household type & 22 & -0.056 \\
\hline Household type & 23 & -0.005 \\
\hline Household type & 24 & -0.014 \\
\hline Household type & 25 & -0.011 \\
\hline Household type & 26 & -0.047 \\
\hline Household type & 27 & -0.027 \\
\hline Household type & 28 & 0.004 \\
\hline Household type & 29 & $-0.150 *$ \\
\hline Household type & 30 & -0.088 \\
\hline Household type & 31 & $-0.163 *$ \\
\hline Household type & 32 & -0.189 \\
\hline Household type & 33 & -0.154 \\
\hline Household type & 34 & -0.075 \\
\hline Household type & 35 & 0.056 \\
\hline
\end{tabular}

Net household income

0.018

Mother class

1. Higher salariat (Ref.)

2. Lower salariat $\quad-0.016$

3. Higher white collar

4. Petite bourgeois

$-0.034^{* * *}$

5. Small farmers

$-0.076 * * *$

6. Higher grade blue collar

$-0.122$

7. Lower white collar

$-0.037^{*}$

8. Skilled manual

$-0.070 * * *$

9. Semi-/non-skilled

$-0.121^{* * *}$

$-0.157 * * *$

Father class

1. Higher salariat (Ref.)

2. Lower salariat

$-0.022^{* *}$

3. Higher white collar

$-0.022$

4. Petite bourgeois

$-0.042 * *$

5. Small farmers

$-0.061$

6. Higher grade blue collar

$-0.038 * *$

7. Lower white collar

$-0.032 * *$

8. Skilled manual

$-0.076 * * *$

9. Semi-/non-skilled

$-0.089^{* * *}$

Mother school qualification

1. Lower secondary or less

$-0.248 * * *$

2. Mid-secondary

$-0.170 * * *$

3. Upper sec. vocational)

$-0.077^{* * *}$

4. Uppper sec. academic (Ref.)

Father school qualification

1. Lower secondary or less

2. Mid-secondary

$-0.196 * * *$

3. Upper sec. vocational)

$-0.124 * * *$

4. Uppper sec. academic (Ref.)

$-0.066 * * *$

Mother professional qualification

1. None

2. Secondary vocational

3. Post-secondary vocational

$-0.078^{* * *}$

$-0.044 * * *$

$0.067^{* * *}$

4. Tertiary vocational

$-0.015$

5. Tertiary academic (Ref.)

Father professional qualification

1. None

$-0.054^{* * *}$

2. Secondary vocational

$-0.067^{* * *}$

3. Post-secondary vocational

4. Tertiary vocational

$-0.047^{* * *}$

$-0.038 * * *$

5. Tertiary academic (Ref.) 
Figure A1.Distribution of monthly net household income (subsample of parents who were observed prior to children's transition to secondary education)

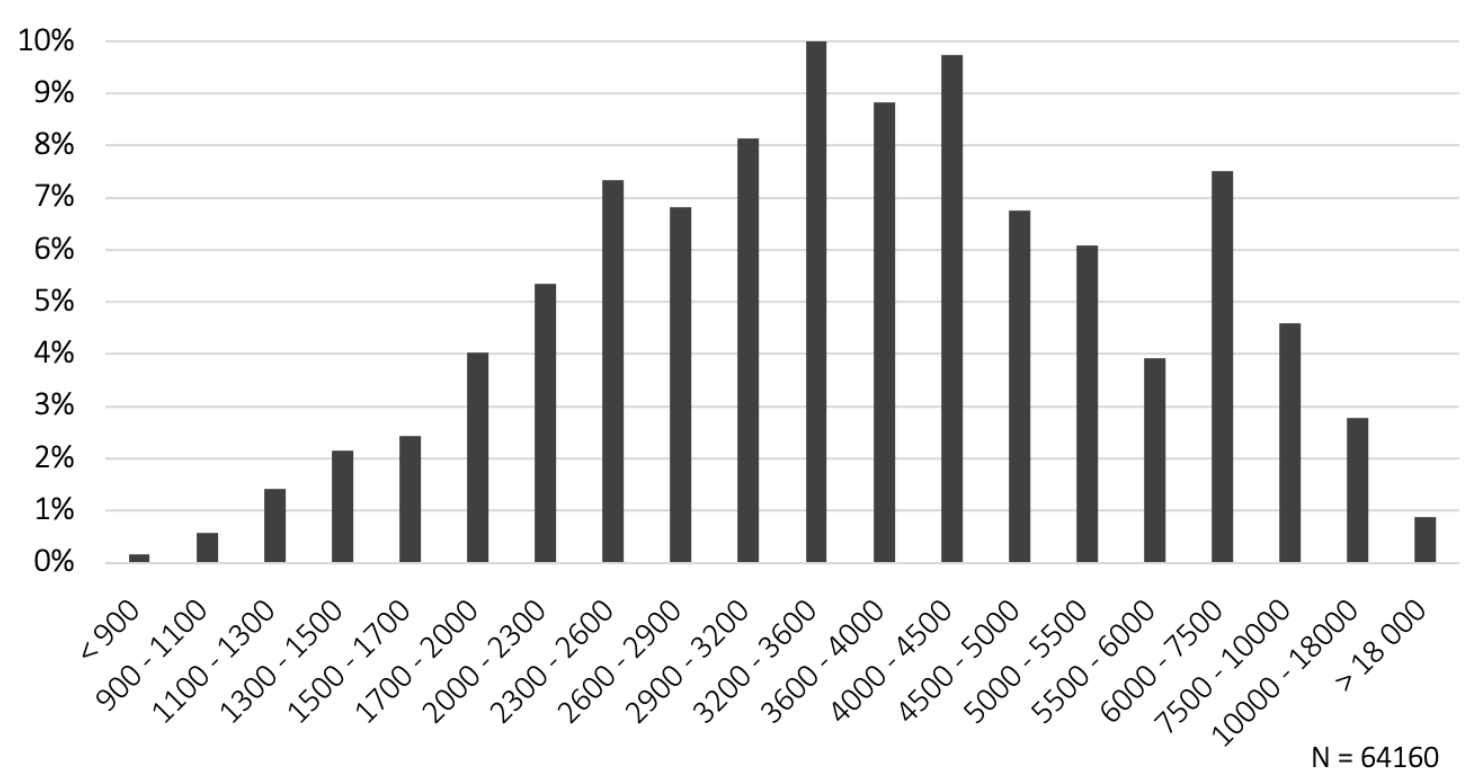


Flgure A2.Association between parental employment status and children's educational track (subsample of children whose parents were observed prior to children's transition to secondary education)

\begin{tabular}{|c|c|c|c|}
\hline Mother & Coefficient & \multicolumn{2}{|c|}{ Coefficient plot } \\
\hline 1. Employer/self-employed & -0.015 & $\longrightarrow$ & \\
\hline 2. Permanent contract & (Ref.) & & \\
\hline 3. Fixed-term contract (long) & 0.014 & $\longmapsto$ & $\bullet$ \\
\hline 4. Fixed-term contract (short) & -0.068 & $\longmapsto$ & \\
\hline 5. Unemployed & -0.021 & $\bullet$ & - \\
\hline 6. Inactive & -0.031 & $\longmapsto$ & \\
\hline \multicolumn{4}{|l|}{ Father } \\
\hline 1. Employer/self-employed & 0.022 & $\longmapsto$ & $\longrightarrow$ \\
\hline 2. Permanent contract & (Ref.) & & \\
\hline 3. Fixed-term contract (long) & 0.006 & $\longmapsto$ & - \\
\hline 4. Fixed-term contract (short) & -0.023 & $\bullet$ & $\longrightarrow$ \\
\hline 5. Unemployed & 0.007 & & - \\
\hline 6. Inactive & -0.016 & $\longmapsto$ & $\longrightarrow$ \\
\hline & -0.15 & -0.10 & 0.05 \\
\hline
\end{tabular}

Notes: Includes controls for net household income and mothers'and fathers' class and education; $95 \%$ Conifidence intervals

Flgure A3.Association between parents' frequency of working evenings and children's educational track (subsample of children whose parents were observed prior to children's transition to secondary education)

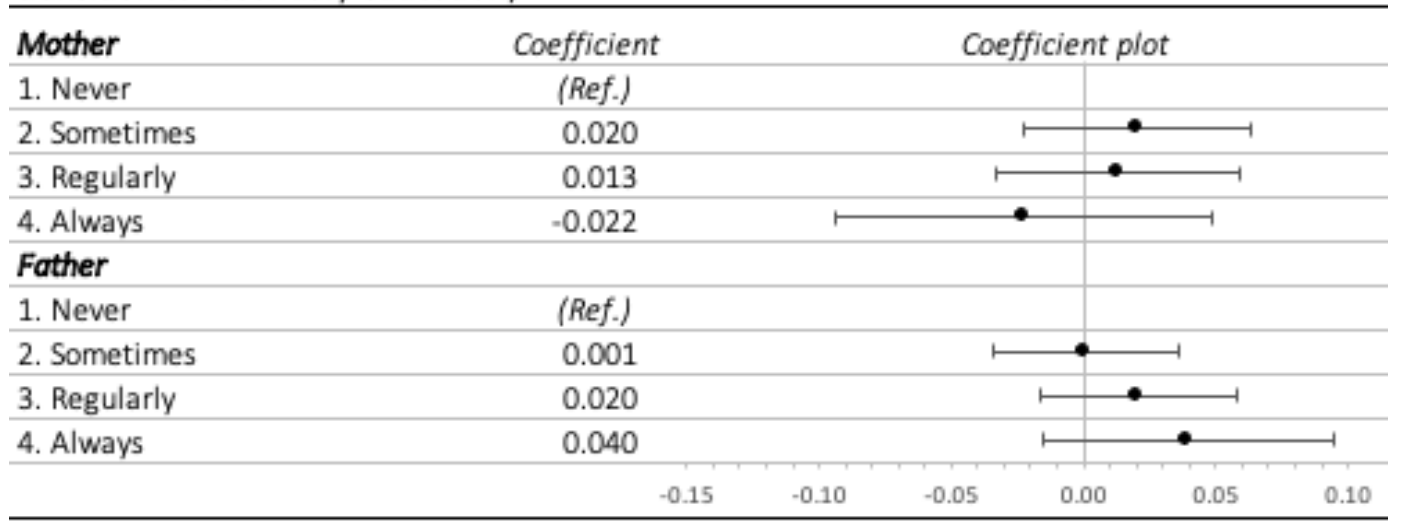

Notes: Includes controls for net household income and mothers'and fathers' class and education; $95 \%$ Conifidence intervals

Flgure A4.Association between parents' frequency of working Saturdays and children's educational track (subsample of children whose parents were observed prior to children's transition to secondary education)

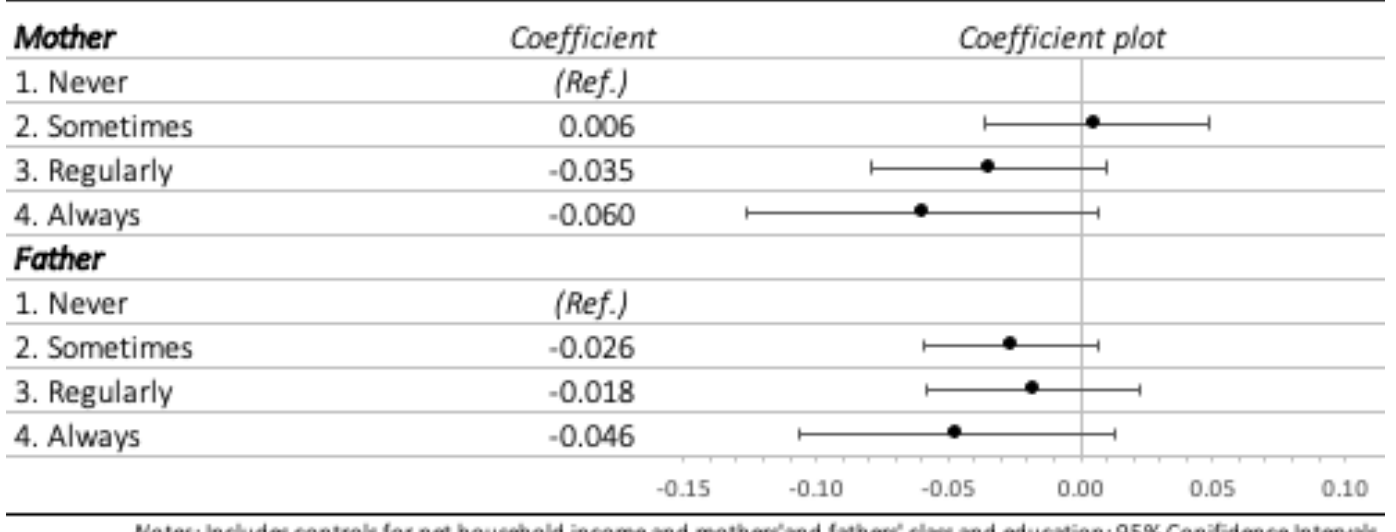

